77
$7 \mathrm{H} 3$ Hahn, C.W.

Sporizoon Parasites 2 certain wishes in the vicinity of Woods Ho, mass., 1915 


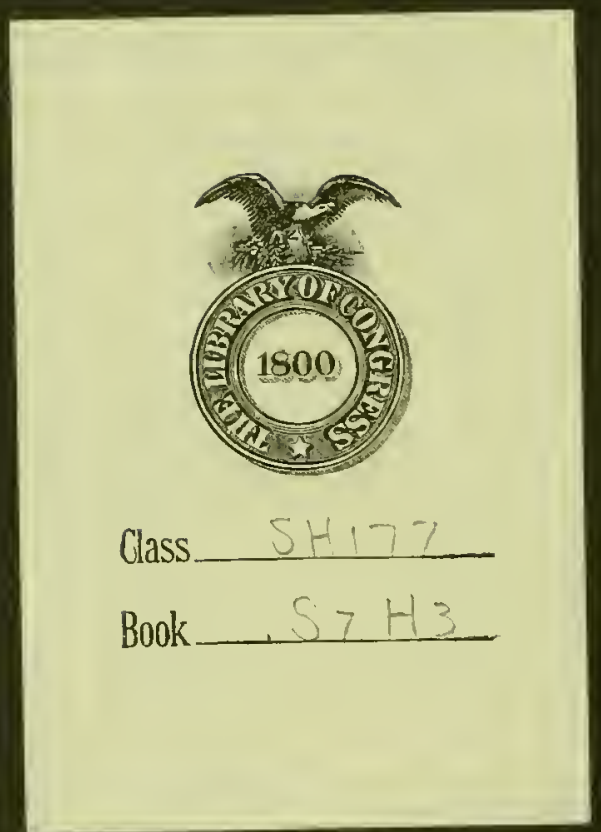


SPOROZOÖN PARASITES OF CERTAIN FISHES IN THE VICINITY OF WOODS HOLE, MASSACHUSETTS

By C. W. Hahn

From BULLETIN OF THE, BUREAU OF FISHERIES, Volume XXXIII, I9I3

Document No. 810 : : : : : : : : : $:$ : Issued April 29, 1915

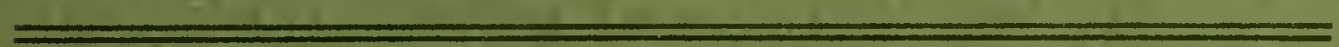

WASHINGTON : $: \quad: \quad: \quad:$ COVERNMENT PRINTING OFFICE $: \quad: \quad: \quad: \quad: \quad: \quad: 1915$ 



SPOROZOÖN PARASITES OF CERTAIN FISHES IN THE VICINITY OF WOODS HOLE, MASSACHUSETTS

By C.W. Hahn

From BULLETIN OF THE BUREAU OF FISHERIES, Volume XXXIII, I9I3

Document No. 810 : : : : : : : : : : : Issucd April 29, I9I5



WASHINGTON $: \quad: \quad: \quad: \quad$ : GOVERNMENT PRINTING OFFICE $\quad: \quad: \quad: \quad: \quad: \quad: \quad$ : 1915 


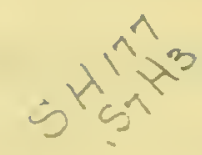

ADDITIONAL COPIES

OP THIS PUBLICATION MAY BE PROCURED FBOM

THE SUPERLNTENDENT OF DOCUMIENTS

GOVERNMENT PRINTING OFFICE

WASHINGTON, D. C.

10 CENTS PER COPY

$\nabla$

n. OF 3

Miv $5 \quad 1915$ 
SPOROZOÖN PARASITES OF CERTAIN FISHES IN THE VICINITY OF WOODS HOLE, MASSACHUSETTS

*

By C. W. Hahn 


\section{CONTENTS}

Occurrence of disease.

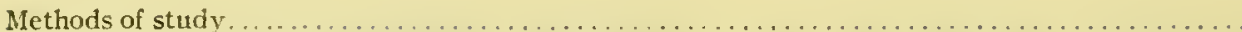

Expcriments to determine character of infection. . . . . . . . . . . . . . . . . . . . .

Pathological condition of the tissues. . . . . . . . . . . . . . . . . . . . . . . . . . . .

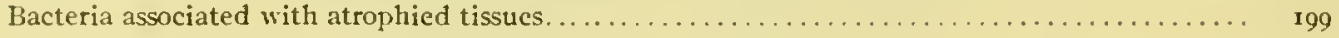

Sporozoa associated with atrophied tissues. . . . . . . . . . . . . . . . . . . . . . . . .

Stages of Myxobolus musculi. ....................................

Chloromyxum funduli. . . . . . . . . . . . . . . . . . . . . . . . . . . .

Protozoa related to those here described . . . . . . . . . . . . . . . . . . . . . . . .

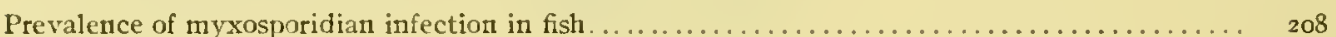

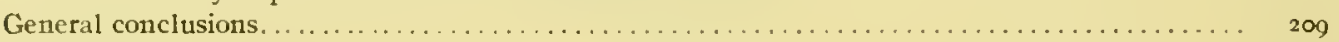

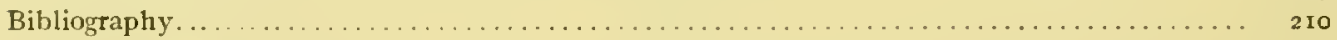

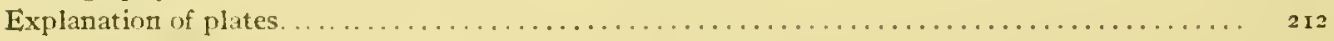




\title{
SPOROZOÖN PARASITES OF CERTAIN FISHES IN THE VICINITY OF WOODS HOLE, MASSACHUSETTS.
}

\author{
By C. W. HAHN.
}

While studying the Sporozoa in different species of fish at Woods Hole, Mass., in 1909, the myxospore of one was observed in diseased killifish, Fundulus heteroclitus and Fundulus majalis. Additional material was obtained and some special experiments were carried out during the seasons of 1910, 1911, 1912, and 1913, the United States Bureau of Fisheries providing the facilities for this and other similar studies at its Woods Hole biological laboratory. ${ }^{a}$

\section{OCCURRENCE OF DISEASE.}

When a number of Fundulus of either of the common species (heteroclitus or majalis) are confined in aquaria for a few days during the warm season, one or more thickened white or pink areas appear upon the integument of some of the fishes. The scales of these patches are more or less loosened. They increase in size and number, and the number of afflicted fishes also increases. The fins when involved become bloody and the fin-rays are exposed. Elsewhere the integument disintegrates and the flesh is laid bare. Considerable excavations into the body muscle are not uncommon. The largest carity of this kind observed was in the head region, measuring about 1o to $12 \mathrm{~mm}$. in diameter and 2 to $3 \mathrm{~mm}$. in depth. Such excavations expose large areas of the skull. When other parts are attacked, loss of blood or penetration of vital parts causes death before the lesion becomes conspicuous externally. The integument is thickened around the sores where the scales are loose. Its color is pink or white. The scales fall out at the edge of the sores. The caudal fin may be completely removed, also the flesh and integument of the tail, thus exposing the vertebræ, before the fish succumbs to the disease. Fish frequently give evidence of weakness and depression even before the flesh has been exposed. There is nothing peculiar about the locomotion except a diminished activity. In certain cases where there is conspicuous inflammation of the integument, especially under the head, the fish may be observed to dart downward, and, with a slight rotation or twist of the body, to scrape the ventral or lateral portion of the head upon the bottom of the aquarium. The fish slowly lose strength, the smaller ones first, and the larger ones not until they are greatly mutilated. Apparently all afllicted fish die unless special care is given to cleanliness, water, and food.

The proportion of fish that are diseased when caught has not been ascertained. The ratio of those that develop integumentary sores in the first day or two to those that are healthy depends to a great measure upon the injuries received in handling the

a Valuable assistance from Dr. Edward Linton and Mr. Vinal E. Edwards is gratefully acknowledged. 
catch. Sometimes 50 per cent of the Fundulus that have been roughly handled, as when stripped for eggs, will become diseased in 24 hours. Of these, half may be dead within 12 hours. If a few crabs happen to be confined in the same aquariun with a large number of Fundulus, they inflict injuries npon practically all the fish and all are soon diseased. Uninjured Fundulus develop the disease infrequently. (See p. 196.) Ronghly speaking, 3 to 4 per cent of the Fundulus that are brought into the laboratory at this season (July and August) and confined in small aquaria liaving but a liter or two of water for each fish, will be found diseased within two days. Within another day or two some of these fish die and a large number die in the course of a week. Diseased Fundulus are therefore almost constantly available.

\section{METHODS OF STUDY.}

Both fresh and preserved tissues were examined microscopically, the method of handling the tissues being as follows: The scales having been removed with forceps, the edge of a slide is drawn over a diseased area with a little pressure, and the mucns and cellular material thus obtained is spread evenly over the surface of another slide; or, a portion of integument or muscle which has been removed with a scalpel is ground between two thick slides by giving to the upper slide a circular motion. It is necessary to use considerable pressure, and at times cut tough fragments with the sharp edge of the upper slide. Under these conditions, both slides may be preserved for observation and still others made from the ground-np material. Some of the smear preparations made in this manner were examined while fresh and others were fixed and stained. Altogether about 85 fish were examined microscopically. Fresh smears which were sometimes supplied with bile and serum were sealed with vaseline, and could then be examined from time to time, during a period of 24 hours.

For sectioning, tissues were fixed in a saturated solution of corrosive sublimate in 35 per cent alcohol with 0.2 per cent acetic acid and 6 per cent formaldehyde; also in the ether-formalin-alcohol mixture given below. Some of the smears were fixed in the same sublimate mixture; others in a solution of corrosive sublimate in 2 parts absolute alcolol and I of ether; still others in a mixture of absolute alcohol (6o per cent), ether (35 per cent), and strong formaldehyde ( 5 per cent). The mercury preparations are stained with a modification of Mayer's hæmatein. (See Hahn, Archiv für Protistenkunde, bd. xvir, no. 3, p. 3 I6, footnote.) Usually the alcolol and formalin preparations are stained in methylene blue or Giemsa's stain. The methylene blue was extracted in a saturate alcoholic (70 per cent) solution of both eosin and orange $\mathrm{G}$. The Giemsa was washed in water, allowed to dry, and decolorized in carbol-xylol, without the use of alcohol. Some of the more recent preparations fixed by either of the above fluids have been more successfully stained by first treating with hæmatein for several hours, then decolorizing in 70 per cent alcohol with i per cent $\mathrm{HCl}$, returning through the alcohols to water, and staining in methylene blue or toluidin blue. After dehydration they were left in a contrast stain (eosin and orange $\mathrm{G}$ ) for a few minutes and rapidly run into 95 per cent alcohol, carbol-xylol, and two changes or xylol. Both smear preparations and sections are mounted in Canada balsam without cover glasses.

Searching is most satisfactorily carried on with an ocular of 1 inch and an objective of one-fifth inch focal distance. A one-twelfth inch oil immersion objective combined with the same ocular for ordinary observation is supplemented, when occasion requires, with a no. 2 compensating ocular. The one-fifth inch objective is not too high to be 
used without a cover glass and reveals most of the details necessary to recognize the presence of Protozoa or other unusual histological conditions. A mechanical stage is indispensable.

Three organisms are involved in most of the Fundulus ulcers, rarely a fourth. A thick, short bacillus is the most abundant. A long, slender bacillus is less common. The Sporozoa are represented by a species of Myxobolus, and in one case a species of Chloromyxum. From the evidence in the following account it will be learned that the primary attack upon healthy tissues, in a certain proportion of the diseased fish, is probably made by the long bacillus. At least a few and probably many of the diseased fish are primarily attacked by Myxosporidia. The short bacillus is more or less incapable of rapid growth in living cells of any kind. While it is not within our province to make an exhaustive study of the fungus diseases, it has been necessary to ascertain to what extent they participate in bringing about these pathological conditions.

\section{EXPERIMENTS TO DETERMINE CHARACTER OF INFECTION.}

The following experiments were carried out in order to gain some accurate information as to the conditions whereby healthy fish are infected and the possibilities of their recovery. At the time it was not possible to discriminate between fish that were infected by a fungus and those that were infected by a sporozoön. It will be apparent that the experiments are not vitally affected by the kind of parasite present.

Forty fish were divided equally and placed in two 5-gallon aquaria. These fish had been seined in the usual manner and brought to the laboratory on board the steamer Phalarope in large milk cans. The trip from the collecting grounds (Menemsha Bight) usually requires about one and one-half hours. The cans accommodate from 200 to 300 fish each. A hose supplies thein with fresh water. The 40 fish used in this case were examined carefully and found to be free from all visible integumentary disturbance.

First stage.-Aquarium no. I was carefully cleaned and sterilized. Aquarium no. 2 had contained diseased fish, and 2 diseased fish were allowed to remain with the 20 fish used in the experiment. Contaminated fish from other sources were always kept in this jar. Both groups were fed about every 48 hours. After a period of II days none of the fish in the clean jar showed any signs of disease. From this fact we concluded that they were free from the disease and suitable for experimentation of a different kind. After the same period ( 11 days) the contaminated jar had one fish with a conspicuous sore. It died a day later.

Second stage.-On the eleventh day one of the fish in each of the two jars was operated upon. A scale or two was removed and the integument pierced with a scalpel just back of and dorsal to the opercle. More diseased fish were introduced into aquarium no. 2. Five days later the fish in aquarium no. I which had been operated upon died. The integument, at the point where the incision had been made, had developed a typical sore. At this time the fish with the pierced integument in no. 2, being a large fish, had not developed a sore of noticeable extent.

Third stage.-On the sixteenth day of the experiment, all fish having recovered in both no. I and no. 2, scales were removed and the integument of all the fish was pierced in the same manner as was done with the two above mentioned. Two days later almost all of those in jar no. 2 had developed marked diseased patches at the very spot where the integument had been pierced. No noticeable change had taken place in the fish of the clean jar. Four days later one fish in jar no. I died from the effects of the rapidly $64023^{\circ}-15-2$ 
advancing disease. Subsequent examinations of the tissues showed that the probable cause of this disease is a myxosporidian belonging to the genus Chloromyxum, being unique in this respect. (See p. 205.) Four dead fish taken from jar no. 2 at this time included two that had been introduced for the purpose of spreading the disease. After seven days the fish in jar no. I were all recovering. The incised integument had closed and appeared a little white. Of those in jar no. 2, two were dead, three were seriously diseased and died within 24 hours, and the others had conspicuous sores. The remaining I4 fish from this time began to show signs of recovery, probably because they were not subjected to contamination and they were fed more regularly. Twelve fish remained in jar no. 1 and had completely recovered before the experiment was discontinued.

In the above experiment the treatment given to the two jars was as far as possible the same. Some fish escaped from both jars by jumping out.

The first stage of this experiment, which corresponds with the first i I days, was not conclusive. One fish, having contracted a fatal disease from a contaminated environment, demonstrates the possibility that fish with apparently healthy integument may acquire the ulcers. The second stage of the test, covering six days, was still less conclusive. But the third stage, covering seven days, showed beyond doubt that the infection enters a lesion of the integument, that contamination favors its entrance; that some of these diseases may be contracted in tolerably pure water, and that lesions which are not contaminated heal completely.

Another experiment of this character was then started, making use of some of all the lots of fish that had been under observation. All were in good condition. Eight fish of fair size were carefully removed from this stock and, by means of a small sterilized scalpel, an incision was made back of the head and a pocket then made under the integument so as to disturb the tissues as little as possible. Into this pocket was inserted a bit of the diseased flesh from sores of four fish taken from different aquaria. As a control, eight more fish of the same size were similarly cut, but nothing was introduced into the pockets. Of the contaminated fish, four died from the disease in two days, the balance in four days. In this case the disease spread over the whole upper part of the body and assumed the characteristic appearance usually encountered. Only one of the controls died. The others healed and recovered completely. From time to time the diseased fish which were introduced into the contaminated jar and those used for the inoculation experiments were examined microscopically. All were infected with bacteria.

This last experiment, covering a period of four days, confirms the results of the previous experiments as to the infectious nature of the disease as well as the inability of the fish to throw off strong cultures of the causal agents. We also learn that when the fish is well nourished and in a wholesome environment, it has considerable natural immunity and recovers readily from the affliction.

In order to prevent the customary mortality from this kind of affliction, care should be taken not to injure the fish while collecting; no crabs or other carnivorous enemies should be confined in the same tanks with the Fundulus, and after establishing them in an aquarium without crowding, they should be fed on alternate days. The aquarium should be kept free from dead and diseased fish. With proper circulation of water, this treatment will no doubt reduce the mortality to a negligible quantity and preserve the fish for several months. 


\section{PATHOLOGICAL CONDITION OF THE TISSUES.}

Those typical sores in which Sporozoa can not be positively demonstrated, and of which a part may be due to bacteria, present the following histological conditions. They are probably primarily exogenous ulcers in which there is at times abundant granular degeneration derived both from lymphocytes and hæmocytes. Sometimes at the nidus of the necrotic area there are small cysts or abcesses containing small lymphocytes. Usually the vascular tissues abound and erythrocytes preponderate. There is a decided tendency at times for the epidermis to form a cicatrix. Again it gives evidence of sloughing off. But so far as the muscle tissue is concerned universal necrosis is common.

The involved epidermis contains numerous nonstaining globules or masses of variable size (fig. $36, \mathrm{pl} . \mathrm{xxI}$ ), as to the exact nature of which we are yet in doubt. They are also to be found in the connective tissue of the dermis and in certain partly atrophied muscle fibers when adjacent to degenerate tissue. They seem to be more numerous in the epidermal cells wherein there are obvious signs of disintegration (pp. 198, 201, 203). Inasmuch as there is a nonstaining zoöglœa or secretion about some of the bacilli that are commonly found in these parts, which frequently prevents them from staining (see p. 200 ), it is possible that these bodies are of the same nature and contain one or more of the bacilli. No doubt many are fat globules, but some are certainly not. Some of these bodies in sections of muscle containing myxoplasms possess a well-defined uucleus. (Fig. 12, pl. xx.)

In smears of integument, it is occasionally possible to find fragments of considerable size having the epidermal cells inore or less filled with the short bacillns referred to above. It is not difficult to prove, by the observation of fresh material or by comparison of tissues of different stages of degeneration, that the short bacillus is seldom found in normal living cells. It is therefore not probable that the primary attack upon the epidermis is caused by this particular organism. The long slender bacillus is less commonly encountered in the dermis and epidermis. There is but little evidence in support of the view that it is the initial cause of epidermal decadence.

The muscle fibers beneath these infected areas present an interesting condition. To the naked eye there seem to be numerous white threads running parallel with the muscle cells. This is especially true of well-advanced ulcers. When seen under the microscope, such flesh has but few normal fibers with fibrillæ and cross striæ. Nost of them have the sarcolemma and interfibrillar connective tissue still sufficiently intact to retain the general external structure of the separate fibers, but the myoplasm is in various stages of degeneration. We conclude, therefore, that the parasite is intracellular and does not pass readily from one fiber to another. The muscle fibers sometimes undergo degeneration more or less uniformly throughout their length. In some cases it is more rapid in the immediate vicinity of the parasites. This we know from sections where the fibrillæ show in places adjacent to degenerate myoplasm in which Sporozoa are numerous. One side or the middle may be far more degenerate than the rest of the fiber. The parasites have probably passed through these regions. The first indication of change is the loss of fibrillation. It is rather difficult to find a parasitized fiber showing normal fibrillation (fig. 13, pl. xx). The pale bands of muscle fibers next become granular (figs. I and 2, pl. xx) and at length the sarcous elements break up into large pieces. Eventually there is total granular atrophy of the fiber within the sarcolemma. In certain cases, usually 
when the atrophy is hyalin, there are considerable elefts in the sarcoplasm. (Fig. 4, pl. xx). These spaces may come to be more or less elosely packed with erythrocytes or leucoeytes, or both, so that when the cytoplasm of the blood cells has degenerated a third and common condition is encountered. The nuclei in various stages of degeneration become densely packed and enlarged. They assume amœboid shapes, large alveoli appear in them, and eventually they fall a prey to the short bacillus (fig. 5 and 6 , pl.xx) elsewhere encountered.

The conditions thus presented are such as to suggest an amøboid parasite which has demolished a muscle fiber and simultaneously broken up into innumerable bacillusshaped spores by schizogony. (See fig. to, pl. xx.) The connective tissue nuclei of the flesh and integument and the nuclei of the gill epithelium give rise to the same degeneration phenomena. Such nuclei may be about equally hypertrophied and massed in such a manner as to completely disguise their true nature. Both muscle and vascular nuelei may oecur in abnormal numbers under the sarcolemma of fibers which are in almost any state of atrophy but without elefts. (Fig. 5, pl. xx.)

In both fresh and stained musele the evolution of a curious artifact was observed. It appears as a dense hyalin body in the sarcolympl, between fibrillæ. (Fig. 3, pl. xx.) Assuming an amœboid form it resembles a rapidly growing organism. (Fig. 2 and 7 , pl. $\mathrm{xx}$.) But the regular distribution (fig. 2 and 3 ) and numerous variations toward a crystalline rosette structure are conclusive evidence of their lifeless nature.

Whatever the active eause of the degeneration of muscle fiber, be it bacteria or Protozoa, the atrophy advanees far into one or more musele fibers without eausing any damage to the adjacent fibers. In cross sections of such tissues there may be a small group of normal fibers cut in section amongst numerous others that are wholly degenerate. Capillaries, arteries, veins, and sheets of connectivc tissue, entirely normal in appearance, may also penetrate these necrotic masses. This is no doubt due to the restraining influence of the sarcolemma upon either the parasite or toxin. As we have already noted, the sarcolemma retains its normal relations in completely atrophied fibers.

Restricting our statements to tissues known to be infected by Sporozoa, there are but two kinds where their action has been observed, namely, muscle, and the connective tissue of the gill. The pathological condition of the musele tissue, in such eases, is not distinguishable, as far as we know, from that which results from the action of bacteria; but if the pathological changes are to be considered as characteristic of a parasite when it is known to be the cause of the atrophy, a careful study of those cases where bacteria are a negligible factor is important. The myxospores, which are the most easily recognized stages of the Myxosporidia, are eommon only in smear preparations and only those which include more or less diseased muscle fibers. These same smear preparations also contain cells identical in appearance to inyxoplasms, pansporoblasts, and sporoblasts, which happen to be the only representatives of the Sporozoa that we have encountered in sectioned material, thus suggesting their myxosporidian eharacter.

Several fragments of tissue, the integument of which was slightly diseased, were sectioned. They give no evidence of myxospores, but the muscle fibers present practically the same degenerative changes to be seen elsewhere. The dermis contains numerous minute unstained lens-shaped structures similar to those described on page 197. These extend into the ends of the adjacent muscle fibers, becoming less numerous in the deeper parts. Such fibers show obrious sigus of atrophy. Elsewhere 
there are numerous deep fibers containing many large cells, which vary in size and have conspicuous nuclei. (Fig. 18, pl. Xxi.) These are confined by the sarcolemma to a very few fibers and extend for a long distance through them. A small cavity only is excavated about each cell. They are usually isolated, though two or more may occupy the same cavity. The sarcoplasm in such cases is much atrophied, being uniformly granular or homogeneous. A sharp line of demarcation exists between the infected and uninfected parts of the muscle fiber, the former being degenerate and the latter striated and normal. Situated amongst the fibers containing the Protozoa are others lacking them but atrophied in a typical manner, the sarcoplasm being broken into irregular fragments. There are several other foreign and unnatural structures in the sections just referred to, about which the details are given on page 203. Muscle fibers packed with blood tissues and degenerate nuclei have not been found in any of the sectioned tissues which contain unmistakable cases of Myxosporidia; but no special significance has been attributed to this fact.

Smears of gill filaments stained with Giemsa stain present the following conditions: Both normal and degenerate tissues are encountered. In some places the cartilage supporting structures have been attacked and are partly disintegrated. The general external form of the supporting tissue, including the surrounding connective tissue and epitheliun, are, as a rule, partly maintained; but elsewhere the degeneration is complete. Epithelium and connective tissue cells disappear completely, leaving the elastic fibers and blood elements. Here, as elsewhere, the nuclei of the latter are most persistent, especially those of the erythrocytes. A large portion of the expressed fluids is composed of an acidophile substance containing odd-shaped portions of the fused nuclei. The spaces between the chromatin threads of the latter having become much dilated, fuse and form large masses of network. These are mechanically separated on crushing the tissue. Such masses of nucleic acid or degenerate chromatin have unbroken connections with the normal blood in the arteries or veins of the less disturbed tissue. Where the blood emerges from partly degenerated blood vessels, they are filled with atrophied erythrocyte nuclei. It seems probable tlat very large masses of homogeneous eosinophil material, which are constantly associated with the degenerate gill tissue, are derived from hæmoglobin, lecithin, etc., of the stroma.

Myxospores abound in these degenerate gill tissues, especially in the purulent residues of degeneration where nothing else remains recognizable. They also occur deep in the connective tissue near the cartilage and amongst the capillaries. The spores, developing spores, sporoblasts, and pansporoblasts, in all stages, are clearly defined, apparently unaffected by the conditions where tissue cells have become wholly atrophied. This fact, together with the great abundance of myxospores and developing myxospores, both occurring in considerable clusters, prove beyond question that the primary cause of necrosis in this case is the Myxobolus. No bacteria or other possible agents have been encountered.

\section{BACTERIA ASSOCIATED WITH ATROPHIED TISSUES.}

The small bacillus above referred to (p. 195) varies greatly in size. The smallest (fig. $8, \mathrm{pl} . \mathrm{xx}$ ) measure less than $0.7 \mu$ in thickness and $1.5 \mu$ in length. The large ones (fig. $9, \mathrm{pl} . \mathrm{xx}$ ) average $1.5 \mu$ in thickness and $7 \mu$ in length. The former are homogeneous when stained. The latter frequently appear to have very conspicuous granules just 
inside the cell wall. These are probably artifacts. The older bacilli (fig. 9, pl. xx) taper at one end. They were at first taken for protozoan spores. These bacilli occur by thousands in and near degenerate epidermis and muscle tissue. It is not unusual to find them grouped in the form of the cell which they have completely destroyed. They are then of nearly uniform size (fig. 10, pl. xx); but between individuals of separate groups, there is often a great difference in size. They stain, as a rule, with methylene blue, gentian violet, toluidin blue, and Giemsa stain. Inside the host cells (fig. 6, pl. xx) and when first set free from them they stain, if at all, with great difficulty. This may no doubt be due to a zoögloic condition. In smears, the stretching of this secretion causes the bacilli to be drawn into long parallel rows. The secretion then resembles elastic connective tissue fibers and the bacteria replace the connective tissue nuclei. At times the zoöglœa is not noticeable. (Fig. S and 10.)

To what extent toxins emanating from the short bacillus are the cause of the death and disintegration of the liost tissues we can judge from the following facts: As already stated, this bacillus is not to be found throughout large areas of atrophied muscle and integument. If the toxin emanating by diffusion from a localized organism brought about the decadence of a tissue, one would expect the evidences of such decadence to indicate a uniform advance of said toxin in the same direction through a given tissue; but, as we have seen, the atrophy of muscle fibers is limited to a certain few in a large number of normal cells, or there may even be a few normal fibers extending through and far into a necrotic region. The same relations prevail more or less in the epidermis. If the short bacillus is to be regarded as a saprophyte, then some more virulent primary organism must be present. In the diseased gills the abundance of $M$. musculi and the extent of injury in its immediate presence point to the sporozoön as the primary agent. There are a few places in the gill tissue where the short bacillus is abundant, but, as would be expected of a saprophyte, in very degenerate tissue only. Such seems to be its relation to all the tissues.

There are also tissues in which nothing but the long bacillus can be recognized as the agent of primary degeneration. While never abundant, it may be observed more frequently than the short bacillus in fresh smears of infected tissue. After about 24 hours the latter appear in clusters in the muscle fibers occupying excavations of regular ovoid contour. The long type occurs less frequently in tissues that are completely atrophied than in those which just begin to show signs of decadence. Fresh muscle, in the latter condition, may have the long bacilli more or less abundantly distributed under the sarcolemma, but never in compact groups, a condition which is characteristic of the short form. In sections, the long type has been encountered, one or two at a time, in muscle fibers at or near the region of advancing degeneration, and occupying irregular transverse clefts in the scarcoplasm (similar to those in fig. 4, pl. xx). But these cavities seen to be much too large to be considered the excavations of so few of these minute organisms. Their toxins may precede them and the transverse cleavage of the muscle fiber may be due to subsequent mechanical forces. On the other hand, the bacillus is quite as likely to creep into the crevices in the sarcoplasm as are the blood tissues (p. 198). Its presence is therefore not necessarily evidence that it is the cause of the crevices. In one stained smear, some of the muscle fibers of which are completely hypertrophied, the long bacillus is very abundant, especially in the connective tissue. There is no evidence of the admixture of fluid from purulent tissue such as is frequently 
common when the short bacillus occurs abundantly; nor are there any of the short bacilli. The normal striated fibers possess few if any of the germs and they seem to be numerous in proportion as the sarcoplasm is degenerate. These are not the conditions we would expect of a virulent parasite unless its primary attack is through the agency of a toxin. There is a second factor to be considered, however, inasmuch as numerous myxoplasms and autospores of $M$. musculi occur in some of the less decomposed portions of the same tissue. With the evidence at hand bearing upon the virulence of the two bacilli, the most natural conclusion is that the short bacillus is a saprophyte, that the long bacillus is either a facultative parasite upon the post tissues, which has been reduced in vigor by the Sporozoa already established therein, or perhaps a true parasite, in which case there are frequent double infections, the long bacillus and Myxosporidia together preparing the way for the saprophytic short bacillus.

The long and short bacilli are easily distingnishable by their size, shape, and habits. The long bacillus is $0.7 \mu$ in diameter and usually at least $2.5 \mu$ long, but it may be $22 \mu$ long, without any noticeable increase in diameter. (Fig. I , pl. xx.) They have tapered ends, especially those which have but recently divided. Sometimes the long type divides, forming short rods, but they are then in chains. They never occur in clusters as in figure $\mathrm{s}$, plate $\mathrm{xx}$. The short type is never coiled, never so long, and always thicker than the long bacillus. They are both encountered in smears which include the fluids of completely broken-down tissues, but the short form is always abundant in such fluids, while the former is rare. One is frequently clustered and in regular pockets, the other isolated or scattered and, if in cavities at all, they are irregular crevices.

\section{SPOROZOA ASSOCIATED WITH ATROPHIED TISSUES.}

From the evidence in the foregoing pages and borne out by that which is to follow, it is certain that a sporozoön causes the primary degeneration of muscle, gill, and possibly integumentary tissues, resulting in pathological conditions which are quite as characteristic as when the bacillus is the primary parasite. In one tissue which was sectioned (fig. $\mathrm{s}$, pl. xxI) the degeneration of the muscle fibers is identical to that where bacteria alone have been observed (p. 200). The atrophied fibers, which contain numerous scattered Sporozoa (p. 198, 203), occur in groups of two or three here and there throughout the fragment of flesh. Frequently, in both sections and smears, degenerate muscle fibers occur in which there are cells similar to the above but with neither nucleus nor cytoplasm stained; also large amœboid masses of granular cytoplasm without any visible nucleus (fig. 13, pl. xx). Usually such foreign cells occur in tissues when either myxospores or multiplicative stages are more or less abundant.

In one or the other of the above stages the sporozoön luas been positively identified with the disease in 18 of the 85 fish which have been examined. On the other hand, many degenerating fibers have been encountered both in smears and sections in which neither Protozoa nor bacteria could be found. In such cases there is about equal lack of evidence that either of the above are the causal agents of such disintegration. While it is probable that the majority of the sores are caused by the inoculation of a wound by a germ, there is less evidence of a primary attack upon the tissues by the bacteria, except through a widespread toxin, than by Sporozoa. In this connection there is probably a significant difference in the external appearance of diseased tissues which are primarily due to the sporozoön attack and those which are caused by bacteria. 
Certain fish in which the diseased parts were conspicuously congested (ventral part of the head, around the anus, and about the eyes) were almost invariably found to contain a large number of myxospores. When we consider the unknown stages of the Sporozoa which, according to the cyclic habit of these organisms, advance from stage to stage in a given culture at nearly the same rate, there is reason to attribute to them more destruction than our observations warrant. Our present lack of knowledge is no doubt due in part to the inadequate stains that have been employed and in part to the confusion of tissue cells with certain stages of the myxosporidian cycle. (See also p. 205.)

\section{STAGES OF MYXOBOLUS MUSCULI.}

Mention is made in the literature of but one other case of mxyosporidian disease of the integument and flesh which is closely allied to that of the Fundulus, namely $M$. lintoni of Cyprinodon variegatus (Linton, I889-1891). With this one exception, similar diseases in other American and European salt-water minnows, as far as we can learn, have not been described. The $M$. lintoni of the Cyprinodon was at first supposed to be identical to the $M$. musculi of Fundulus. But very recently a tumor of the variegated minnow was encountered. (See p. 206.) Both the spore and the tumor are markedly different from the common condition of Fundulus.

The myxoplasm of $M$. musculi produces a great many pansporoblasts, each with a single spore. There is a large vacuole in most of the spores which is the characteristic iodinophilous vacuole of the genus $M y x$ obolus, to which the parasite undoubtedly belongs.

Of the life history we have the spore, pansporoblast, possibly the myxoplasm, schizont, and multiplicative or autospore. In but 3 of the 18 fish which harbor Sporozoa have we stages (figs. 20, $21,26,27, \mathrm{pl}$. XXI) that can be unmistakably connected with the spore. By association in the same tissue or by the appearance and staining reaction we have probably identified the myxoplasms and autospores.

According to Auerbach's (I9I0) description of $M$. bergense, the spore terminates the life cycle in a given host and starts a new cycle in a new host. We can but assume that the trophoplasm of $M$. musculi likewise arises in some way from a primary myxospore. The trophoplasm (fig. 12, pl. xx) is difficult to stain, and therefore its sporozoön properties are not always certain. (See also Chloromyxum properties, p. 205.) Spherical or oval spaces in the diseased myoplasm and in the epidermal cells (possibly identical, fig. $36, \mathrm{pl}$. xxI, and p. 197) are very abundant. These are probably multiplicative trophoplasms, unless we have confused them with fat or other nonstaining substances. Sometimes these bodies have nuclei (fig. 12) which, though usually faint, may stain deeply. It is not impossible that some of these small trophoplasms may be those of the Chloromyxum. When large, the trophoplasms have a granular structure (fig. I $3, \mathrm{pl}$. xx) and are doubtless preparing to undergo schizogony. We have encountered but five or six such schizonts. In one series of sections they are associated in diseased muscle fibers with cysts containing many spores. (Fig. I4, pl. xx.) The amœboid form of the mature schizont is characteristic and distinguishes it from the smaller forms. The schizont in figure 13 is $33 \mu$ wide by $74 \mu$ in length. Some of the cysts are about this size, but figure 14 , which is $19 \mu$ wide and $24 \mu$ long, is a section through the small end of a cyst of only moderate size. The cysts are found both within and between the muscle fibers. They contain several hundred spores, the nucleus of which, like that of the trophoplasm, has at times little affinity for the stains we have employed. The spores sometimes 
appear to be spherical in form (fig. $14, \mathrm{pl} . \mathrm{xx}$ ) and vary somewhat in size. They have a small faintly-staining nucleus and hyalin nonstaining cytoplasm. Isolated spores and masses of spores recently discharged from the cysts also occur in the smear preparations associated with the intrafibrillar masses of material that appear to be equivalent to schizonts. These spores also occur in small numbers in the diseased gill where myxospores and sporoblasts are to be found in very great numbers.

The occurrence of a multiplicative process of reproduction amongst the Myxosporidia in the manner here described is not uncommon. We have authentic cases in gall parasites of the flounder, and they have been described in M. pfeifferi (Keysselitz, 1908) and in Henneguya gigantea (Nemeczek, I91 I). While there is no question but that there are multiplicative spores, our evidence that the spore here described is such is, as with the trophoplasm, far from conclusive. Judging from the meager evidence at our disposal, there is about equal reason for considering it a young sporoblast or a young trophoplast. It is more harmonious to regard these amœboid spores as the progenitors of both multiplicative and propagative trophoplasts and the oval spores, which are described below (p. 204) as sporoblasts, more especially since they apparently arise by free cell formation and in smaller numbers.

The propagative and sporoblast stages have been encountered frequently in both sections and smear preparations. One series of sections of diseased integument and muscle (referred to on p. 198), which were cut approximately at right angles to the body surface, contains numerous large cells (fig. 18 , pl. Xxi) with small well-stained (with hæmatein) nuclei. Some of the muscle fibers are cut obliquely. They lie in the midst of healthy tissue and under integument which is apparently healthy. These myxoplasms are of oblong or spherical form with more or less even surface. The cytoplasm is tolerably homogeneous and does not retain the stains. The karyoplasm is also unstained, but the chromatin is somewhat conspicuous. These cells occur abundantly throughout 60 or more sections, in 6 to 8 adjacent fibers, also in other distant fibers. Upwards of a hundred perfectly normal fibers around them have not a single foreign cell. Such cells are always intracellular. The sarcoplasm is considerably modified. The fibrillar structure is lost and the appearance is almost homogeneous.

A cell similar in every respect to the myxoplasm just referred to, occurs abundantly in smears of muscle tissues. It stains less readily than do leucocytes and has smaller nuclei with less conspicuous chromatin. Myxospores and pansporoblasts have been found in their midst, in fact are to be found on slides where this type of cell occurs and not elsewhere. In this connection it is interesting, and perhaps additional evidence of relationship, that the same sore from which the sections containing these myxoplasms (fig. $18, \mathrm{pl} . \mathrm{xx}$ ) were made also supplied a smear preparation containing numerous myxospores and pansporoblasts represented in figure 26 , plate $\mathrm{xxI}$. The sporoblast resembles the myxoplasm of smear preparations in shape, clear, nonstaining cytoplasm, size, and feebly staining (with methylene blue) nucleus. It is for the above reasons that this type is assumed to belong in the propagative cycle.

There is a wide range of conditions to be seen in the nuclei of these myxoplasms, as well as some variations in size. Some densely-staining, cigar-shaped bodies (fig. 17, pl. $\mathrm{xx}_{1}$ ) almost devoid of protoplasm are embedded in the sarcoplasma, and others are closely applied to the myxoplasms (fig. 18, pl. $\mathrm{xx}_{\mathrm{I}}$, near right-hand upper corner). The 
conditions suggest conjugation, but the stages are too few to indicate a succession of events. One myxoplasm contains two oblong spores. Elsewhere, replacing a degenerated muscle fiber, are numerous small cysts ( $12 \mu$ in diameter) with eccentric nuclei, which contain from four to ten or a dozen clearly defined oblong spores (fig. 16, pl. xx). These spores are found abundantly in other fish. (Fig. I9, pl. xxi.) They appear to arise by free cell formation. They are characterized by a transparency and a failure to stain that recall botls the trophic stages and the sporoblasts. 'The nucleus, however, does stain faintly. It is quite large when the spores are set free. The latter measure $4 \mu$ by $2.5 \mu$ and sometimes assume a spherical or amœboid form. Between this condition and the mature sporoblast we lack recognizable connecting stages. They are not far removed, however, from the latter, which are spherical cells with very large nuclei. (Fig. 35, pl. Xxi.) These occur in the gill above mentioned and have there been definitely connected with the myxospore. The pansporoblast has been encountered, along with spores and sporoblasts, in fresh smears of muscle. These are apparently identically homologous to those described for $M$. pfeifferi in the gills of the barbel (Keysselitz, 1908). If so, the sporogenesis there related would appropriately apply to M. musculi. Many stages in the genesis of the spore are represented in one of our smear preparations. These have propagative stages (Keysselitz, 1908) as follows: First the sporoblast with large nucleus (fig. 35, pl. xxI) and two-parted pansporoblast (sporocyst) (fig. 22, 23, pl. xxI), which, according to Keysselitz, arises after a process of autogamous conjugation. The sporocyst apparently sets free the sporocytes before sporogenesis has proceeded far (fig. 21, pl. xxI). Giemsa stain does not reveal all the nuclei concerned in sporogenesis. Valve cells are formed (fig. 24, pl. xxi) before the polar capsules appear as large spherical bodies (fig. 25, pl. xxI). Later the myxospore becomes elongated and tapered (fig. 20, 26, pl. xxi). Two preparations have multitudes of immature spores. They are all free from the sporocyst protoplasm and have thick valves. It is therefore rather perplexing to explain figures 20 and 26 . Perhaps the spore is about to be discharged in figure 20. Considerable variation in this respect occurs amongst some of the gall Myxosporidia.

There are myxospores in 12 of the 85 fish examined. In but 3 of these do they occur in great numbers. With two exceptions (in diseased gills), the myxospores are not assembled in a manner that would suggest their origin from cysts or masses of pansporoblasts, as is common in other species of Myxosporidia. The two cases referred to may not be interpreted as evidence of this condition, but rather that the pansporoblasts, where very numerous, have been packed close together. There are at least a tlousand well-stained spores in the preserved tissues. Not one occurs in the 10 tissues of which sections have been made. But those same tissues which contain spores have supplied all the propagative myxoplasms.

The myxospores are very small (fig. $28,29, \mathrm{pl}$. xxi). They average $14.3 \mu$ in length and $6.7 \mu$ in width. In one fixed individual the plane at right angles to that passing through the polar capsules is presented. It measures $6.7 \mu$ in thickness, from which we coirclude that they are approximately circular in section. But another fresh spore was flattened in a plane perpendictlar to that of the polar capsules and sutures to about two-thirds its width (fig. $30, \mathrm{pl} . \mathrm{xxI}$ ). The polar capsules of myxospores average $6.5 \mu$ in length and $2 \mu$ in thickness. When extruded the filament is three to four times the length of the spore (fig. $29, \mathrm{pl} . \mathrm{xxI}$ ). Coiled within the polar capsule, the filament makes from 
1o to 14 turns (fig. 26,28 , pl. $\mathrm{xxI}$ ). In young spores the valves are quite thick and may be seen at the edges as a pale border to the spore, but in mature spores they are thin and almost invisible. Young spores are shorter $(12 \mu)$ and wider $(7.5 \mu)$ than the mature spores and the polar capsules are not so long $(6 \mu)$. They lengthen out as they approach maturity. When young, the nuclei stain with great difficulty, if at all. The sporoplasm occupies all the space at the large end of the spore. A large vacuole is nearly always visible in the sporoplasm. There are also dense areas and from I to 10 nuclei. (Fig. 20, 28, pl. xxr.) The nuclei are unstained in figure 29, plate xxi. There are sometimes seven greenish-blue nuclei (fig. $28, \mathrm{pl}$. xxI) and three rather irregular dark-blue bodies between the polar capsules. It is not possible to be sure that this (10) is the maximum number as some of these are ill defined. A number of spores have their nuclei attached near the large end of each polar capsule, thus identifying them as the "polar capsule" nuclei. Probably the remaining four belong to the sporoplasm. It is not possible to recognize the "wall nuclei" at this stage, and the "resting nuclei" of the pansporoblast are doubtless lost.

\section{CHLOROMYXUM FUNDULI.}

The Chloromyxa which have been observed in the muscle of other fish (p. 208) are not identical to that found in Fundulus. C. quadratum, which resembles the latter, has myxospores measuring $6 \mu$ in dianeter by $5_{\mu}^{\mu}$ along the polar axis, while the Chloromyxum of the Fundulus measures $7 \cdot 5 \mu$ in diameter and $6 \mu$ along the polar axis and differs in shape. The spore of $C$. quadratum, when seen in line with the polar axis, has the sides deeply concave, and in the other plane it is more pointed. The polar capsules are also much shorter. They also differ in the relation of the spore to the pansporoblast and in the pathological effects. (For description of spore of $C$. funduli see p. 208.) No reference to a myxospore of this character has been found by the writer. The name C. 'funduli has therefore been applied to this species.

The myxospores of $C$. funduli have been encountered in but one fish. If the myxoplasm occurs in other preparations, it has not been possible to identify it, although many suspected myxoplasms exist. It is not very probable that they are at all uncommon. They do not take up a particle of such stains as we have employed. The single slide containing this species is a smear preparation made from the diseased flesh of a fish which died in jar no. 1 of the experiment reported on page 196. It is stained with Giemsa stain.

The muscle of this fish is in an advanced stage of decomposition. When the fresh slides were examined no myxospores were noticed, being difficult to see without a stain, but the sporoblasts were observed without recognizing their importance.

Bacteria are present on the slide but lacking in the muscle fibers. The decadence of the muscle must in this case be ascribed to the Chloromyxum, which is abundant in the hypertrophied muscle. The muscle is full of cavities containing unstained myxoplasms and sporoblasts which are identical in appearance to those of many other preparations of diseased Fundulus. While this case introduces the possibility that many of the Fundulus cancers may be caused by Chloromyxum funduli, it gives rery substantial support to the agency of Sporozoa as the cause of these diseases. Since Chloromyxum and Myxobolus are not uncommon in muscle tissue, double infections are to be expected. But having failed to encounter myxospores of the Chloromyxum in over 100 stained 
preparations that have been examined, we are inclined to consider the Myxobolus more abundant and therefore the more common causal agent.

The myxospore of $C$. funduli is about $7.5 \mu$ in diameter, with a polar axis somewhat shorter $(6 \mu)$. At right angles to the polar axis, it is circular. There are four polar capsules, which taper to the apex of the spore, curving so as to conform to the constriction of the spore, which provides it with a blunt pointed apex (fig. $3 \mathrm{I}, 34, \mathrm{pl}$. xxI). There are four conspicuous nuclei (black), one near the base of each polar capsule. The sporoplasm is stained a pale blue by the Giemsa. The polar capsules do not stain (fig. 3 I, 34, pl. xxi). There are occasional myxospores of considerable size to be seen inside the sporoblasts when the latter do not take up a particle of stain. Such clear hyalin amoboid pansporoblasts are numerous tbroughout the sarcoplasm. They vary in size from a diameter of about $2 \mu$ to four or five times the diameter of the spore.

\section{PROTOZOA RELATED TO THOSE HERE DESCRIBED.}

Numerous Myxosporidia parasitic upon either integunent, gill epithelium, connective tissue, or muscle of fish have been described by other authors. About most of them we have very meager information. M. lintoni (Linton, I889; Gurley, I 893) of Cyprinodon variegatus (short minnow), as already stated (p. 202), more closely resembles the parasites of Fundulus than any other species of which we know. The difference at first seemed to be slight and to be easily accounted for by a difference in the age of the spores. But when a case of the Cyprinodon tumor was finally obtained and examined, the indentity of the parasites in the two hosts, as well as the nature of the lesions, was found to be different. The "irregular fungoid elevations," described and figured by Linton and observed again by the writer, are of the nature of cysts containing spores, located in the integument, whereas the elevated scales in Fundulus are due to an infection of the epidermis by bacilli and a subdermal atrophy of the muscle. No tumor or spore-filled cyst has ever been encountered. The Cyprinodon tumor which we examined developed in a comparatively short time, probably less than a week, though the period can not be accurately stated. It caused the death of the fish the day following that on which it was first noticed. After the death of the bost, the tumor was $8 \mathrm{~mm}$. wide by $10 \mathrm{~mm}$. long, and caused a conspicuous elevation from the back of the fish anterior to the dorsal fin, about 2 to $2 \frac{\mathrm{L}}{2} \mathrm{~mm}$. thick. It was of a yellowish-pink color when seen through the slightly pigmented integument. The scales were practically undisturbed and the integument was completely intact, in this respect differing remarkably from the Fundulus sores. Beneath the tumor, the flesh contained intrafibrillar myxoplasms and sporoblasts with occasional spores, while the tumor itself was almost wholly a mass of myxospores, the latter numbering millions. We have already described (p. 197) a totally different condition in the Fundulus, resulting from the M. musculi.

There is such a difference in the appearance (Linton, s 889, fig. 3) of the spores that they are readily distinguished. One can not be certain, however, that such differences are not due to the comparison of different stages in the development of spores of the same species. We have shown that the spores of $M$. musculi grow longer as they mature and the spore wall becomes thinner ( $p .205$ ). This fact would explain in part the discrepancy in the dimensions of the spores from the Fundulus and Cyprinodon. But, since the spore of $M$. lintoni measures $13.9 \mu$ in length, $11 \mu$ in width, and $S \mu$ in thickness (at right 
angles to the planes of the two polar capsules), and the mature spore of $M$. musculi measures $14.3 \mu$ in length by $6.7 \mu$ thick, and from 4 to $6.7 \mu$ in width (see p. 204), in individuals of apparently the same stage of development, it still seems tbat a sufficient discrepancy in size exists to supplement the marked differences in the pathological conditions. It may yet prove that the latter are due to the influence of different hosts, inasmuch as we have one case of a Fundulus with a typical $M$. musculi lesion, but having spores indistinguishable from those of $M$. lintoni in either size or appearance.

M. lintoni presents another contrast to the conditions in Fundulus. In the former, calcareous bodies were observed amongst the spores by Linton (i 889 ) and the writer, whereas nothing of the kind has ever been encountered in the hundreds of Fundulus tissues which we have examined.

Although the name $M$. lintoni was for a time retained for the Fundulus parasite, the present state of our knowledge will not permit of this assumption. The species "musculi" has been adopted because of the interesting and characteristic attack wbich the trophoplasm makes upon muscle fibers.

The spore of Myxobolus oviformis (Thelohan) resembles $M$. musculi very much in appearance, but is less tapered and slorter (Thelohan, 1894).

The following, for one reason or another, are also of interest in their bearing upon M. musculi. A "Myxosporidian" of unknown genus and species was found by Linton (1899) in the connective tissue of the entire body of Notropis megalops Rafinesque (albcolus Jordan), the shiner. The epidermis is marked by dark purplish blotches. The scales are absent in most cases. A "Myxosporidian" of unknown genus and species was observed by Lieberkühn (1854) in the connective tissue of Gastereosteus aculeatus (stickleback). The skin is said to have contained cysts. The conditions seen to be unlike those in Fundulus. Cyprinus leuciscus (Müller, I841) has been observed with tumors in the integument caused by a species of Myxobolus. M. oblongatus Gurley produces cysts under the scaleless shin of the head region in Catostomus tuberculatus Le Sueur (Gurley, 1891, I893, p. 234). M. transovalis Gurley (1893) of Phoxinus (Clinostomus) funduloides Girard, occurs under the scales and external to the epidermis. "It forms a thin discoidal mass situated in the center of the concave undersurface of the scale." That it is not identical with M. musculi is certain from the dimensions of the myxospore (length $6 \mu$, breadth $8 \mu$, the diameter of which, at right angles to the polar axis, is greater than through the polar axis. We have very scanty information concerning the $M$. strongylurus (Gurley, r 893, p. 247), which is found encysted in the skin of the head of Synodontis schal; of M. momurus (Gurley, r 89 r, p. 4I6), known from cysts in the subcutaneous intermuscular tissue of A phredoderus sayanus Gilliams; of Henneguya nüsslini Schuberg und Schröder (Leger, 1906), which is found in the connective tissue of the dorsal fin of the trout; of M. gigas Auerbach (1907), which thickens the integument at the ventral angle of the gill in Abramis brama Linnæus (bream); and of a Myxobolus of unknown species described by Borne in 1886 (Gurley, i 893, p. 244), which causes great tumors over the surface of Leuciscus rutilis.

In Coregonus fera there occurs a common disease of the integument caused by a species (M. zschokkei, Gurley, r 893; Zschokkei, r 884), the myxoplasm of which is not known. The cysts lie in the subcutaneous connective tissue and between the muscles. It causes irregular thick patches on the skin, from which the scales drop. 


\section{PREVALENCE OF MYXOSPORIDIAN INFECTION IN FISH.}

The infection of muscle tissue by Myxosporidia is quite common in fish. A parasite belonging to the genus Chloromyxum occurs in the flesh of the young herring and young alewife (Linton, 1891). Both the pansporoblast and spores of a Chloromyxum have been found abundantly by the writer inside the fibers, and the spores also assembled elsewhere in large cysts. A fuller account of this species will be published later. The muscle cells of Callionymus lyra are also subject to an intracellular parasite (Glugca destruens Thelohan, I891; Henneguy et Thelolan, 1892; Gurley, I893), the myxoplasm of which has not been observed. It causes the muscle fibers to undergo degeneration. Chloromyxum quadratum (Thelohan, 1894) also occurs in the muscles of this fish. It is also reported in the flesh of Coris julis, Syngnathus acus, Trachurus trachurus (Minchin, 1903) and Nerophis aquoris. In Cottus scorpio the muscle tissue is attacked by Pleistophora typicalis (Thelohan, 1890 , and 1891 ; Gurley, 1893). Both pansporoblast and spores have been found, but they are intercellular in position. The muscle fibers are clisplaced but do not degenerate. Leptotheca pcrlata (Gurley) occurs in the muscles of Acerina cernma Linnæus. Of these species there are none that closely resemble $M$. musculi. Numerous cases of Myxoboli are known to inhabit gill tissues. Aucrbach (1911) lists 22 species of Myxobolus which have been described in the gills of fish. But we have encountered nothing that might be considered identical to M. musculi.

The disease of Fundulus is remarkably like that which has so frequently caused epidemics amongst the barbel (Barbus barbus Linnæus) of European rivers. The latter is caused by $M$. pfeifferi Thelohan (Raillet, 1890; Ludwig, I888; Thelohan, 1894). It produces both tumors and ulcers and occurs encysted and free in muscle, liver, kidney, spleen, and connective tissue. The tumor when formed does not at all tinses break through, either into the body cavity or to the outside. It is not an integumentary parasite at the beginning as those of Fundulus seem to be. The tumor commonly occurs amongst the connective tissue and the muscles of the body wall. The parasite may be encysted in a thin restraining membrane produced by the host. Numerous individuals of about the same age tend to gather in groups and become isolated in tube-like cysts. The muscle fiber is invaded and undergoes a "vitreous alteration" (Thelohan, i 893) leaving "yellow granulations as degeneration products" (Keysselitz, 19o8). Thelohan's figure 5, plate vir (Thelolian, 1994), representing a muscle fiber containing myxoplasms in transverse crevices recalls, very vividly the appearances we have encountered in the degenerate muscle of Fundulus (fig. 4, pl. xx). The tumors may soften and become a "stinking abscess containing spores" (Ludwig). M. pfcifferi passes through distinct cycles of development which is no doubt the case in $M$. musculi. In April it is in a vegetative stage in which the multiplicative reproduction prevails; later propagative reproduction is encountered and myxospores are developed. The rate of advance of the disease depends upon the temperature (Keysselitz).

Both Keysselitz and Thelohan describe bacteria in tissues of diseased barbel. Keysselitz says bacteria contribute liberally to the formation of the tumors. These bacilli are found only in the tissues infected by Myxosporidia. They prevent the growth of connective tissue and bring about degeneration (gangrene) of the tissue.

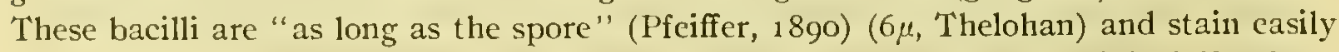
witls methylene blue and gentian violet. (This is also true of the bacilli of Fundulus 
diseases.) Pfeiffer mentions threads attached to these bacilli. A coccus is also occasionally found. The presence of bacteria is therefore not necessarily an indication that they are primary as causal agents of disease since $M$. pfeifferi is known to be the cause of the barbel disease.

\section{GENERAL CONCLUSIONS.}

I. The sores of Fundulus are usually caused primarily by lesions. These may occasionally be due to parasites such as leeches, distomes, and copepods, but usually to rough handling and carnivorous enemies.

II. At least four kinds of germs invade these lesions and bring about hypertrophy of the tissue elements and decomposition, namely, two species of bacteria and two species of Myxosporidia.

III. There is doubt as to the virulence of the bacteria. One species at least is saprophytic. There is no doubt as to the virulence of the Myxosporidia when present.

IV. Cleanliness, careful feeding, and acration bring about recovery in practically all injured fish. It can not be claimed that fish which are known to have Myxosporidia are curable.

V. The trophoplasm of both species of Myxosporidia attacks the muscle fibers, that of the M. musculi also attacks the gill connective tissue.

VI. Blood elements, especially nuclei, give rise to abundant artifacts which are closely associated with the parasite involved.

VII. Sporogenesis of the Myxobolus occur infrequently in the muscle and gill tissues.

VIII. Multiplicative spores are probably formed in M. musculi in addition to primary sporocytes.

IX. The myxoplasm of both C. funduli and M. musculi are stained with difficulty and are therefore not easily fonnd. 
AUERBACh, Max.

\section{BIBLIOGRAPHY.}

I907. Weitere Mitteilungen über Myxobolus æglefini Auerbach. Zoölogischer Anzeiger, bd. xxxr, p. 386-39r. Leipsig.

1910. Biologische und morphologische Bemerkungen ïber Myzosporidien. Zoölogischer Anzeiger, bd. $x x x v$, p. 57-64. Leipsig.

19I1. Unsere hentigen Kenntnisse über die geographische Verbreitung der Myxosporidien. Zoölogischer Jahrbucher, Abtheilung für Systematik, bd. 30, p. 47 I-494

BORNE, MAX VON DEM.

I886. Handbuch der Fischzucht und Fischerei, p. 2 II, fig. 2 I5.

GURLEY, R. R.

I891. On the classification of the Myxosporidia, a group of protozoan parasites infesting fishes. Bulletin United States Fish Commission, vol. $x 1,1891$, p. 407-420. Review it Centralblatt für Bakteriologie und Parasitenkunde, bd. 15, p. 86-88.

I893. The Myxosporidia or psorosperms of fishes, and the epidemics produced by them. Report U. S. Commission of Fish and Fisheries, 1892, p. 65-304, pl. I-47.

HenNeguy, F., et Thelohan, P.

I892. Sur un Sporozoaire parasite des muscles de l'ecrevisse. Comptes rendus hebdomadaire Société de Bioiogie Paris, t. 4, p. 748-749.

KEYSSELITZ, G.

I908. Die Entwicklung von Myxobolus pfeifferi Thelohan, Theil I und 2, Archiv fïr Protistenkunde, bd. II, p. $25^{2}, 276-308$. Jena.

LEGER, L.

1906. Sur une nonvelle myxosporidian de la tauche commune et de la truite indigene. Comptes rendus de l'Academie des Sciences, Paris, t. I42, p. 655.

LIEBERKÜHN, $N$.

IS54. Über die Psorospermien. Mïller's Archiv, p. 9-10, 22, 24, 354, taf. 2, fig. 28; taf. I4, fig. 9-12. LiNTON, EDWTN.

1889-1S91. On certain wart-like excrescences occurring on the short minnow, Cyprinodon variegatus, due to psorosperms. Bulletin United States Fish Commission, vol. IX, I889, p. 99-102, pl. xxxv; ibid. p. 359-36r, pl. cxx, fig. 1-3. Review in Centralblatt für Bakteriologie

LUDWIG, H. und Parasitenkunde, $189^{2}$, bd. I I , p. 475 .

1888. Über die Myxosporidien krankheit der Barben in der Mosel. Jahrbuch des rheinischen Fischerei Vereins, Bonn, p. $27-36$.

Minchin, E. A.

1903. A Treatise on Zoölogy. Edited by E. Ray Lankester, pt. I, fasc. 2, p. I50-36r.

MÜLLER, J.

1841. Ueber Psorospermien. Müller's Archiv für Anatomic und Physiologie, p. 477-496, pl. I6. Abstract in Microscopical Jo urnal, London, 184I-2, p. $123^{-124}$

PFEIFFER, L.

189o. Die Protozoen als Krarkheitserreger, Jena, I ed.

PLEHN, M.

1905. Über die Drehkrankheit der Salmoniden (Lentospora cerebralis) Archiv für Protistenkunde, bd. 5, p. $145-166$, taf. 1 , fig. 7 . Jena.

RAILLET, M. A.

ı89o. La maladie des Barbeaux de la Marne. Bulletin Société Centrale d'Aquiculture, Paris, 210

$$
\text { t. } 2 \text {, p. II } 7-\text { ז2o. }
$$


THELOHAN, P.

I89o. Contribution a l'etude des Myxosporidies. Annales de Micrographie specialement consacrees a la bacteriologie, aux protophytes et aux protozoaires. P. I, t. 2, p. 193-213. Paris.

I8go. Recherches sur le developpement des spores chez les Myxosporidies. Comptes rendus hebdomadaire de la Société de Biologie. Paris, t. 2, p. 602-604. Abstract in Journal Royal Microscopical Society, I89o, pt. 2, p. I94-195.

I891. Sur deux sporozoaires nouveaux parasites des muscles des poissons. Ibid., t. 62, p. I68-I72. IS93. Alterations du tissu musclaire dues a la présence de Myxosporidies et de microbes chez le barbeau. Ibid., t. 5, p. $26 ;-270$. Abstract in Centralblatt für Bakteriologie und Parasitenkunde, bd. 14, p. 532 .

1894. Recherches sur les Myxosporidies. Bulletin Scientifique de la France et de la Belgique, WIERZEJSKI, A. t. 26, p. 100-394, p1. 7-9. Paris.

I898. Über Myxosporidien des Karpfens. Anzieger der Akademie der Wissenchaft in Krakau, März. Résumé in Bulletin International de l'Academie des Sciences de Cracovie, Comptes rendus des seances, $1898, p$. I $29-9_{45}$. Cracovie.

ZsCHOKKE, F.

1884. Psorosperms de Coregonus fera, Archives de Biologie, t. 5, p. 234-235, pl. Io. 


\section{EXPLANATION OF PLATES.}

With the exception of figures $20,27,30$, and 35 , the drawings were made with the aid of a camera lucida. For figures 3,5 to I I, I 5 to 17, I 9,2 I to $26,28,29,31$ to 34 , and 36 a no. I 2 Bausch \& Lomb compensating ocular and one-twelfth inch oil immersion objective were used. For figures I, 2, 12, I4, and IS a Bausch \& I,omb I-inch occular was employed with the same objective. The I-inch occular and a one-fifth inch objective were used in figures 4 and I3. All figures have been reduced to two-thirds the size of the camera images. The tube length was i $60 \mathrm{~mm}$. and the camera arm $90 \mathrm{~mm}$.

The figures are numbered approximately in the order of developnent. Figures 2, $3,5,6,7,8,9$, and 10 are made from the same slide, and figures $13,14,16,17,18,26$, and 28 are from the same fish.

\section{PLATE NX.}

FIG. I. A bit of infected muscle from a smear of a sore on the side of a small Fundulus heterclitus in the first stage of disintegration. Fixed in corrosive sublimate and acetic acid and stained with Mayer's hæmatein. The pale bands of the fiber are beginning to become granular at one end. Fibrin threads have been spread over it in making the smear preparation. (X860.)

FIG. 2. A bit of degenerating muscle fiber. Numerous artifacts and a degenerate erythrocyte nuclcus occur in the sarcoplasm. The granular striæ are degenerated sarcolymph. Note the sareoplasm is also becoming granular. ( $\times 860$.

FIG. 3. From a smear of a bit of degenerating muscle in a sore on the side of Fundulus majalis. The integument more or less disintegrated, scales entirely absent. Fixed in absolute alcohol, ether, and formaldehyde. Stained in methylene blue, orange G, and eosin. Sarcous elements have lost their sharp rectangular form and are becoming granular. A characteristic muscle artifact is distributed between the sarcostyles and some are just beginning to become amœboid in form. ( $\times 2000$.)

Fig. 4. A characteristic appearance of a degenerating muscle fiber which may or may not be a later stage than those represented in figures 2 and 3. Neither bacteria nor Myxosporidia are necessarily present in these spaces. Both have been encountered there. ( $\left.X_{400}\right)$

Fig. 5. A fragment of degenerating muscle upon and into which erthrocytes and leucocytes have entered. The cytoplasm of the latter is disintegrated and the nuclei arc in an advanced stage of degeneration. ( $\left.\times_{2000}\right)$

FIG.6. A typical mass of degenerate nuclei containing unstained bodies which are probably zoöglœa containing the short bacillus. There are cords of this material in which the bacilli are faintly visible. Such white areas are not merely transparent spaces but thick masses with stainable protoplasm above or below. ( $\times 2000$.)

FIG. 7. Artifacts from decomposing muscle fibers. In fresh muscle these are common after to to 12 hours, appearing first between the sarcostyles. Older stages assume a more compact form. (See figures 3 and 2.) The stain is a homogeneous pale blue. Maximum length 8.9". ( $\times_{2000 .)}$

FIG. 8. The short bacillus. An isolated group near which are located cells contairing white ovalshaped bodies like those in figure 6 . Note the variation in size and shape. That one near the " $X$ " sign measures I. $5 \mu$ by $7.4 \mu$; that near the " + " sign measures 1.8 $\mu$ by I.I $\mu . \quad(\times 2000$.$) (See also fig. 10.)$

F1G. 9. Short bacillus older than figure 8. Nearly the maximum size. Note the taper toward one cnd and the stainable granules. The latter are probably artifacts. Left-hand upper one measures $5.2 \mu$ by $1.4 \mu . \quad\left(\times_{2000}\right)$.

FIG. Io. A ciuster of long bacilli which have caused the complete breakdown of a tissue cell and rest in situ. $\left(X_{2000 .}\right)$

Fig. II. Several of the long type of bacilli which are located just under the sarcolemma of a muscle fiber that shows the first signs of degeneration. The small individual in the middle below has dimensions as follows: Length, $4.8 \mu$; thickness, $0.7 \mu$. (X2000.) 
Fic. 12. A section cut diagonally through a muscle fiber. This fiber is adjacent to the dermis. On the inner side the sarcoplasm is hypertrophied, on the outer side it retains the fibrillation. The oval bodies ase interpreted as trophoplasms of the $M$. musculi. The large one has several spherical bodies which take a deep hæmatein stain, presumably nuclei. ( $\times 800$.

FIG. 13. A muscle fiber in which there are the first evidences of disintegration. It contains two or more large trophoplasts or schizonts. The appearance of the cytoplasm is like that of other stages, pale and unstained, there being no sign of the nucleus. There is evidence of a complex system of pscudopodial extensions of the cytoplasm which is characteristic of the Myxosporidia. Large indi. vidual $84.7 \%$ by $192.5 \mu$. $\left(x_{4}+00.\right)$

FIG. 14. Multiplicative spores of M. musculi, presumably derived from a large trophoplasm such as figure 13 . There is no cyst wall. In adjacent scctions are fragments of the schizont nuclei mingled with the spores. The spores stain feebly with eosin and orange $G$. The nuclei are not stained deeply. I9. $3 \mu$ in diameter. ( $\times 860$.

Fig. 15. A myxoplasm of M. musculi in muscle from a smear preparation fixed with absolute alcohol and ether and stained with methylene blue. One side overlies a nucleus of the muscle fiber. The palc bands of the muscle fiber may be seen. The muscle stained deeply and the parasite pale. The protoplasm is fincly granular and there is only a suggestion of a cytoplasmic network. The nucleus is vaguely stained. $\mathrm{r}_{3.4 \mu}$ by $18.6 \%$. (X2000.)

FIg. 16. Formation of sporoblasts of M. musculi. This cyst is one of a mass numbering several hundred which occupy a position where a muscle fiber has been completely destroyed. The ro spores stain very feebly. They lie in slight cavities of the protoplasm. Diameter of cyst I2u; length of spore $4 \mu . \quad(\times 2000$.

\section{Plate XXI}

Fig. 17. A passible microgamete of $M$. musculi from amongst the numerous myxoplasms of muscle fibers adjacent to that shown in figure I8. The motile shape of several such structures, the small amount of cytoplasm, and close approximation to some of the large myxoplasms are noteworthy. (See right-hand upper region of fig. 18.) $6.5 \mu$ by $2.2 \mu$. (X2000.)

FIG. 18. A section of a muscle fiber of Fundulus heteroclitus cut crosswise at a slight angle. The scales in the region of this infection had dropped off, and the area was almost white, being slightly discolored by blood. The tissue was fixed in corrosive sublimate and acetic acid and stained first in Mayer's hæmatein, then in methylene blue, later in eosin and orange G. One of the structures in the sarcoplasm, that to the left in the middle, is the nucleus of a muscle fibcr. The others are stages in the propagative cycle of $M$. musculi, primary and secondary sporoblasts. The large one in the middle, at the top, is $12.6 \mu$ in length and $5.9 \mu$ in width. ( $\times 860$.

FIG. Ig. Three young sporoblasts of $M$. musculi from the smaller type of cysts represented in figure 16 , plate $\mathrm{xx}$. Note the increase in the size of the nuclei. They are typically free from cytoplasmic stain. (See C. funduli, fig. $3^{\mathrm{r}}$ ) Lower individual $4 \mu$ by $2.5 \%$ ( $(\times 2000$.

FIG. 20. A fresh sporoblast of $M$. musculi containing a spore which is almost mature. From a deep cavity in the flesh back of the head. Interesting in connection with figure 26. (Free-hand drawing, not to scale.)

FIG. 21. Sporocyte of M. musculi expelled from pansporoblast. It forms the first stage in the series represented by figures 23,24 , and 25 . The nucleus is small and faintly stained, as is the rest of

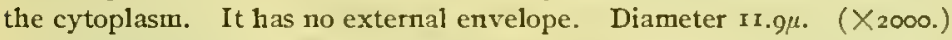

FYG. 22. A pansporoblast of M. musculi (sporocyst) with two daughter cells, the nuclei of which are undergoing autogamous conjugation. ( $X_{2000 .)}$

FIG. 23. A pansporoblast of M. musculi after the autogamous conjugation and subsequent division of the nuclei.

FIG. 24. A sporocyst of $M$. musculi which has been set free from the pansporoblast. Apparently the sporoplasm remains attached to one myxospore (fig. 20), and the other is almost devoid of external protoplasm. The two wall cells are clearly visible, but without nuclei. The capsule nuclei are probably formed but do not stain. One of the Iz nuclei happens to be in a suitable condition to take the stain .

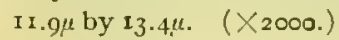

FIG. 25. A myxospore of M. musculi with a remnant of protoplasm. Two polar capsules are beginning to form. ( $\times 2000$. 
FIG. 26. A sporocyst of $M$. musculi from a smear of diseased integument of the mouth and head in front of the eyes. Elsewhere the sporocysts have less cytoplasm. It is the only one encountered in this condition. The failure of the nuclei to take the stain is characteristic. The myxospore is immature, being less slender than older myxospores. The details of the polar capsules are very transparent and stain dark blue, while the spore wall is a very pale blue. The vacuole and sporoplasm are prominent, but the nuclei of the spore can not be clearly discerned. Sporocyst, $17.8 \mu$ by $23.8 \mu$; spore, I $4.8 \mu$ by $7.4 \mu$; polar capsule, $7.4 \mu$ by $2.2 \mu$. There are ${ }^{3}-14$ spirals in the filament. Fixation: Absolute alcohol, ether, corrosive sublimate, acetic acid. Stain: Mayer's hæmatein, methylene blue, orange G., eosin. (X2000.)

F1G. 27. A sporoblast of $M$. musculi from a fresh smear of degenerated muscle taken from a deep cavity (the same as fig. 20). Easily distinguished from tissue cells by the three nuclei. Protoplasm contains much coarsely grauular matter. (Drawn free-hand, not to scale.)

FIG. 28. Myxospore from the same slide as figure 26. The mature spore, when compared with that in the pansporoblast, is longer and more pointed at the polar end. The vacuole is probably an iodinophilous structure. The coiled filaments make II to I 2 turns. The polar capsule wall is visible, but the spore wall can not be clearly seen. The valves and sutures are also indistinguishable. While there are as many as $I_{2}$ blue and green bodies present, one can not be sure that all of them are nuclei. Seven or eight bodies are moderately conspicuous. Two lie in the wall of the polar capsules and are doubtless the capsule nuclei. $1_{4} .8 \mu$ by $6.2 \%$. ( $\left.\times 2000.\right)$

F1G. 29. A myxospore of M. musculi from large sores on each side of the tail of a Fundulus heteroclitus, caudal fin entirely gone. Fixed in absolute alcohol and ether, stained with methylene blue. Six unstained nuclei in the sporoplasm and one large vacuole. Filament discharged. Spore, $7 \cdot 4 \mu$ by $16.4 \mu$. Polar capsule, $2.2 \mu$ by $7.4 \mu$. (×2000.)

FIG. 30. Diagram of the cross section of a fresh myxospore of $M$. musculi as if seen from the end. The specimen was lying so as to preseut the edge of the valves to view. It is obviously flattened. The polar capsules also appeared to be, but one can not be certain about this. The sutures are straight and symmetrical. Fixation: Alcohol, ether, formalin; Giemsa stain. (This drawing not made to scale.)

[Figures $3 \mathrm{I}$ to 34 are all from the same smear preparation of diseased muscle from a dead fish, being one of those taken from jar no. I (see pp. 195, 196).]

F1G. 31. Pansporoblast of Chloromyxum funduli embedded in a degenerated muscle fiber. The contained myxospore has taken up the stain, but the protoplasm of the pansporoblast is absolutely devoid of visible structure. Note the even contour of the characteristic lobose pseudopodia. $\quad 15,2 \mu$ by 12 $\mu$. (X2000.)

FiG. 32. One of a group consisting of free young myxospores of $C$. funduli. Like the mature myxospores, they stain readily, but their nuclei are not differentiated. They are, as a rule, not quite so irregular, but the pseudopodia are always small and angular. Note the contrast between these and the pansporoblasts. $3 \cdot 7 \mu$ by $4 \cdot 5 \mu$. (X2000.)

F1G. 33. Myxospore of $C$. funduli. The outline is approximately circular. The sporoplasm is homogeneous but dense around the four polar capsules, doubtless because of the greater thickness at this point. The four nuclei are always associated with the polar capsules, hence are doubtless capsule nuclei. Diameter, 8.9 . (X2000.)

Fig. 34. Myxospore of $C$. funduit seen from the side. Note the sporoplasm is not much denser about the polar capsules. The sporoplasm tapers to a blunt apex. In many it is more pointed. The polar capsules have long, curved, tapering necks with the large ends far apart. The capsule nuclei alone stain. $8.2 \mu$ by $6.7 \mu$. (X2000.)

Fig. 35. A fresh sporoblast of $M$. musculi from the same slide as figures 20 and 27 . The cytoplasm is rich in granules. The nucleus is very large and has a conspicuous karyosome. (Not drawn to scale.)

Fig. 36 . An isolated epidermal cell derived from a mass near the margin of an advanced ulcer, most of which have numerous unstained bodies like those in the muscle fibers (fig. I2, pl. $\mathrm{xx}$ ). From sections. The epidermal cell is not typical in appearance, but the unstained bodies are, and are identical to those in the adjacent slightly atrophied epidermis. ( $\left.X_{2000}\right)$ 

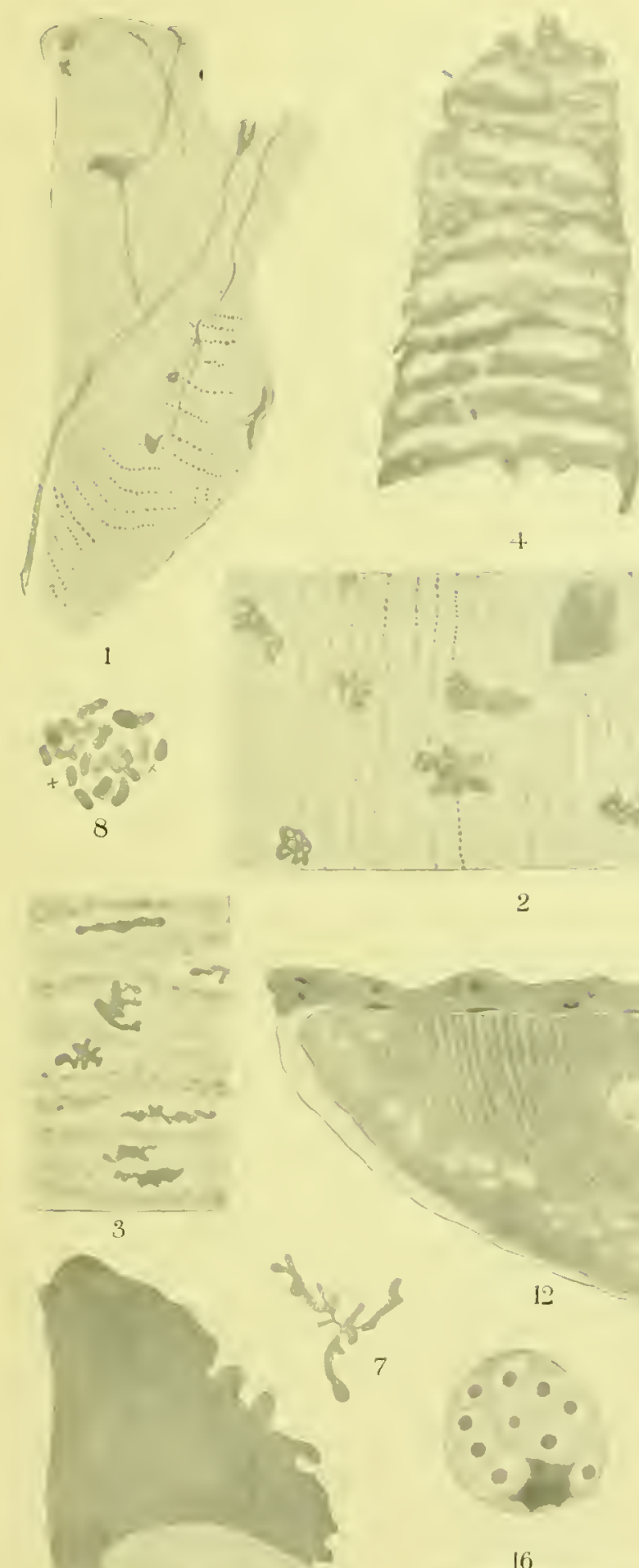

TE
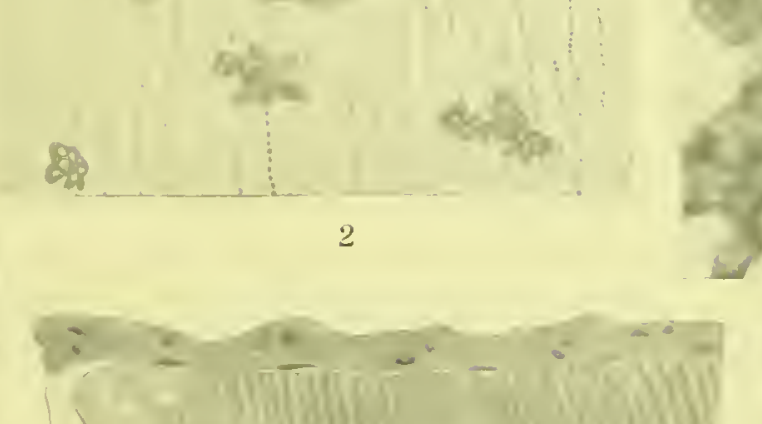

2
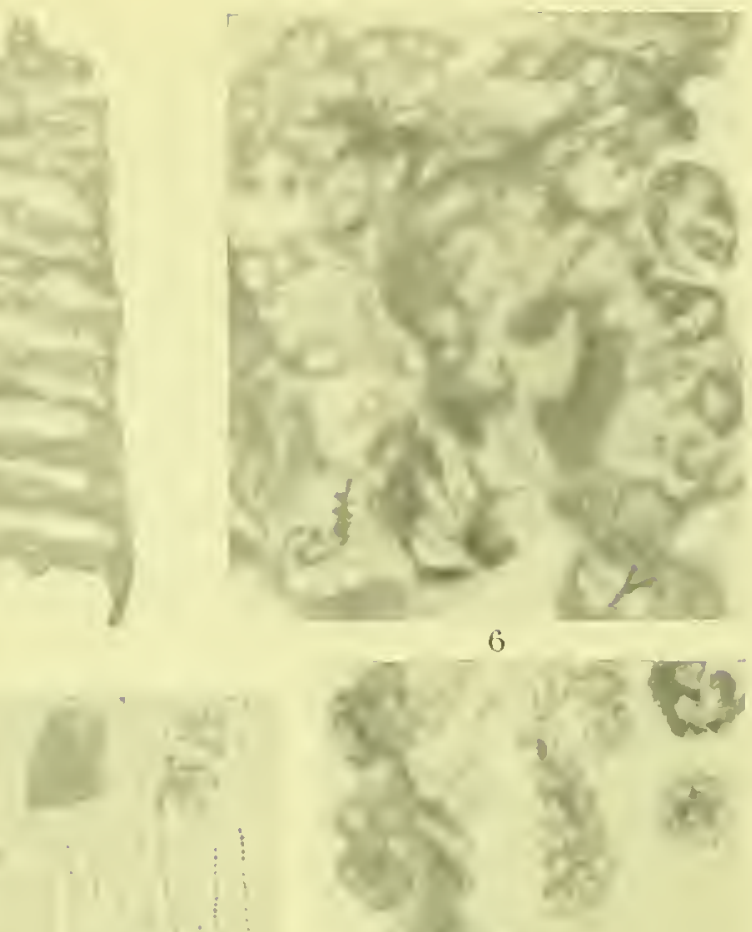

8
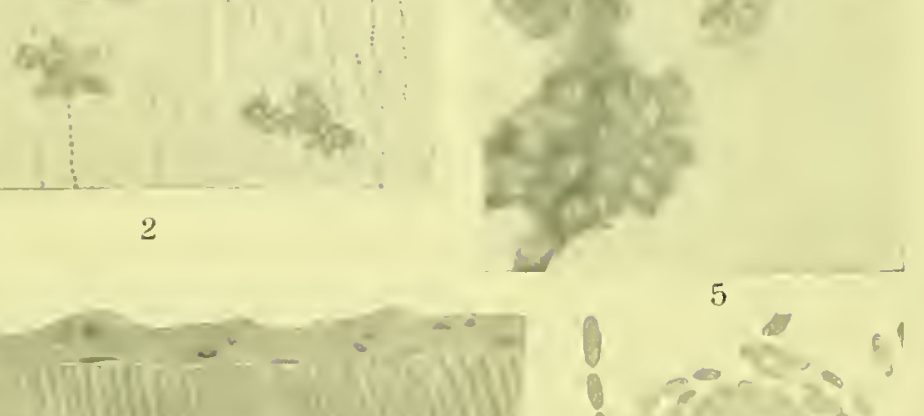

$0 x^{2}-20$

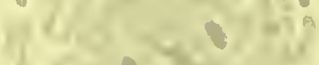

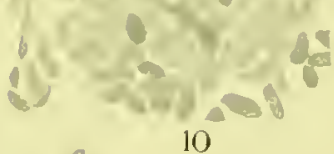

C
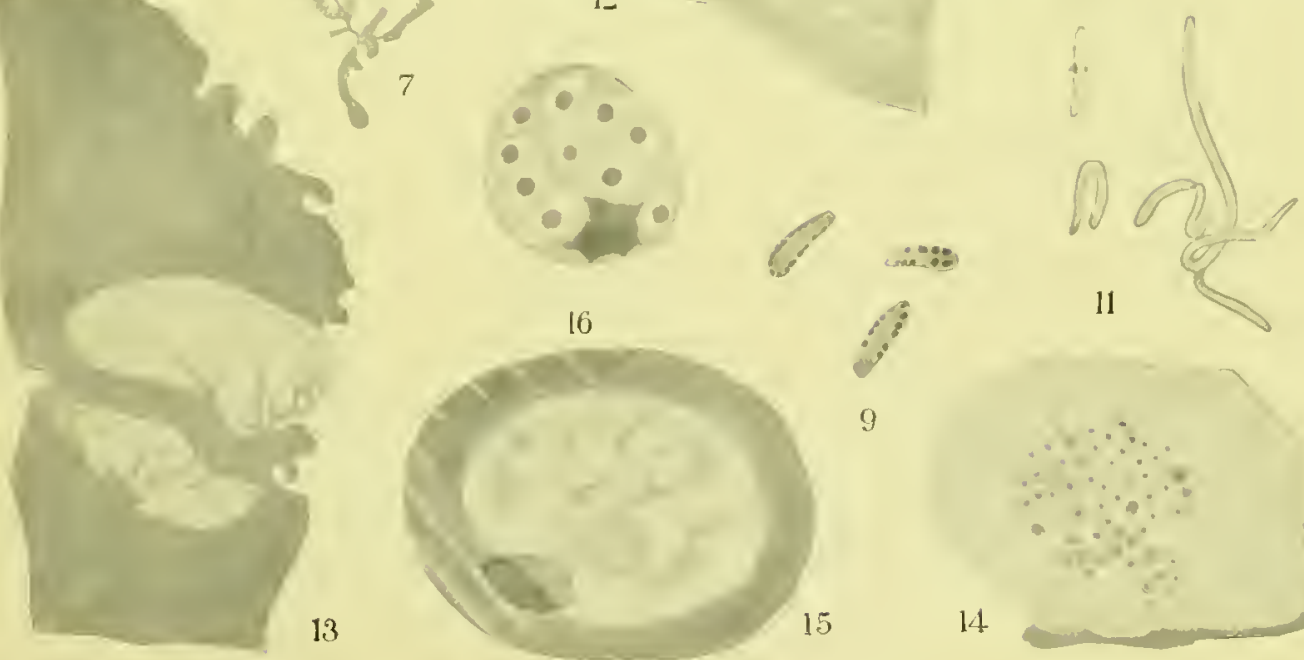

15

14

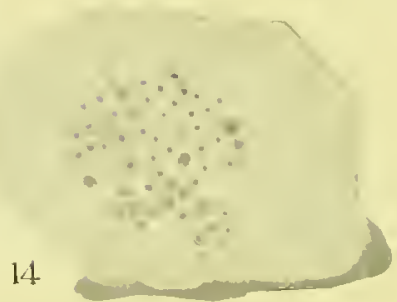


But.I. [., S. B. F., I9I3.

PLATE XII.

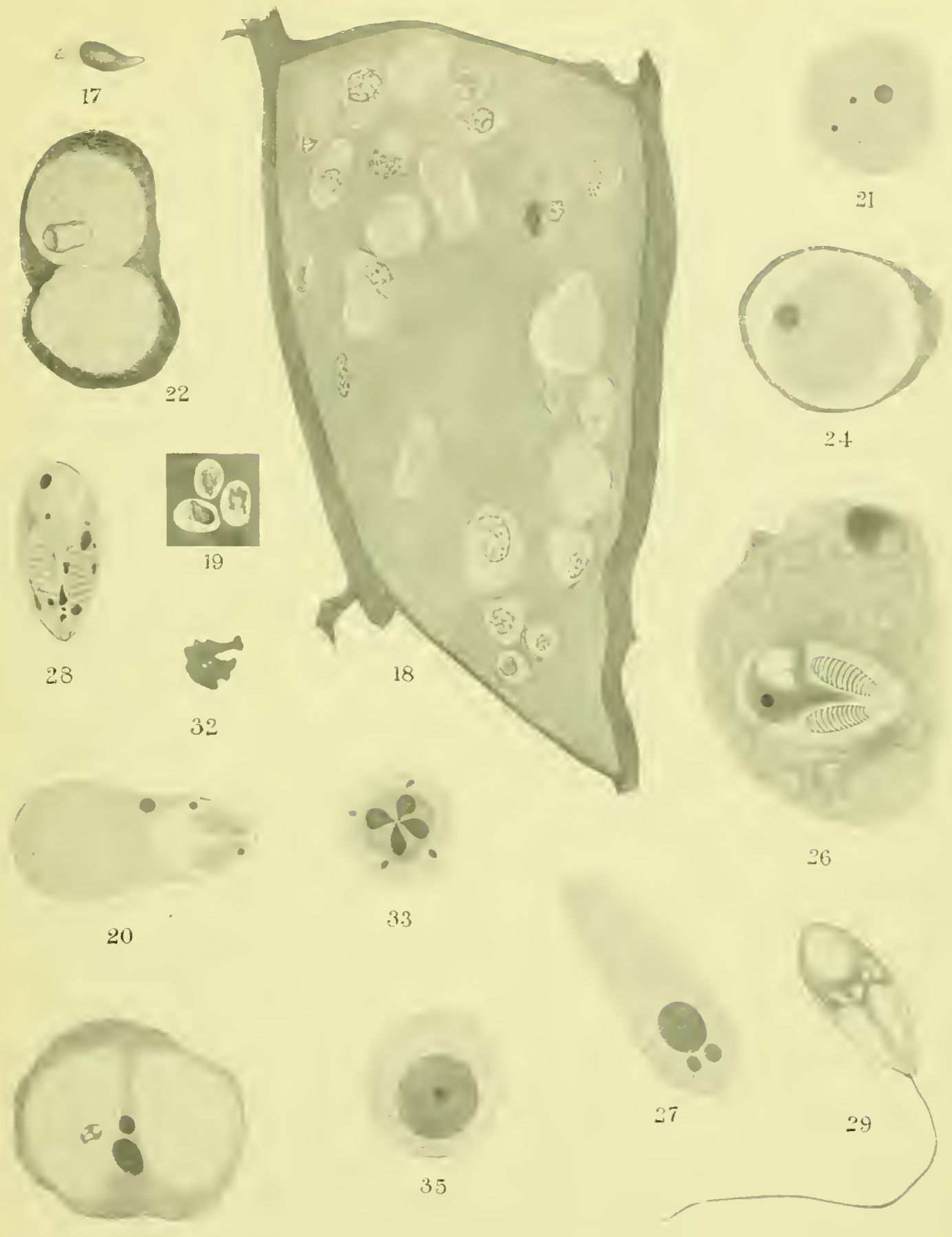

23
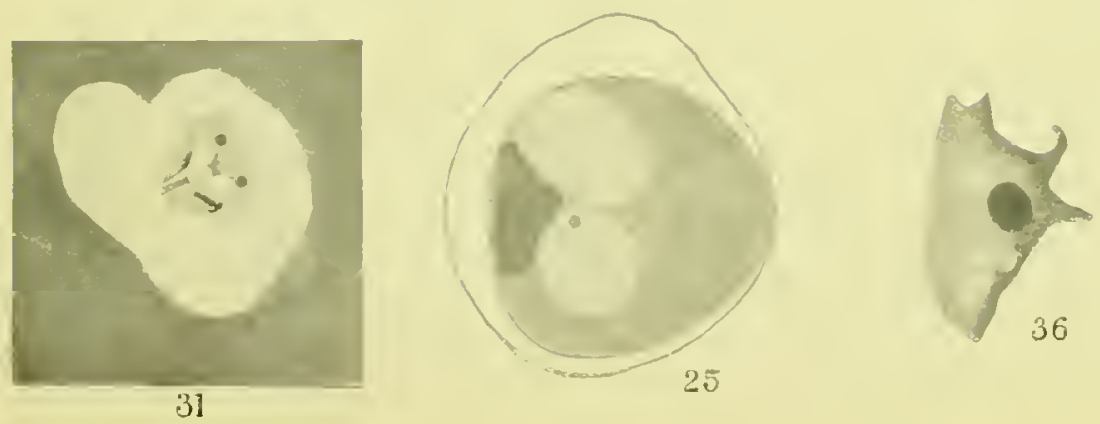

30

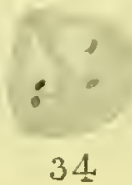









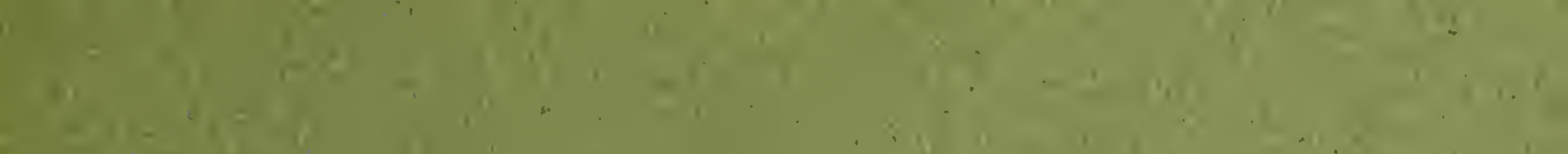

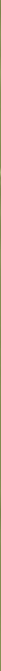

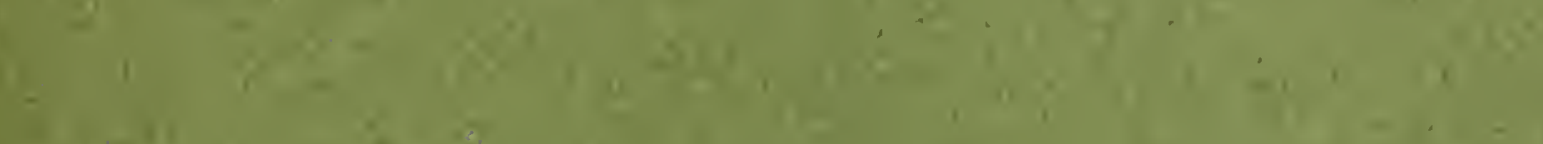

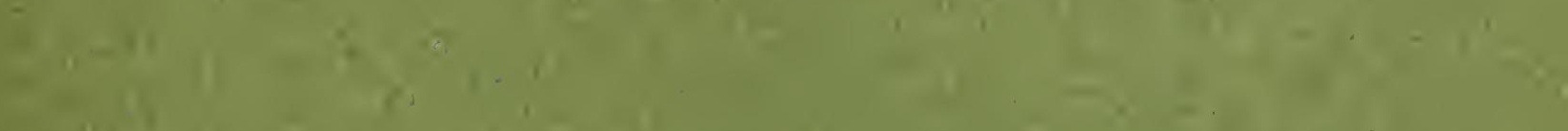

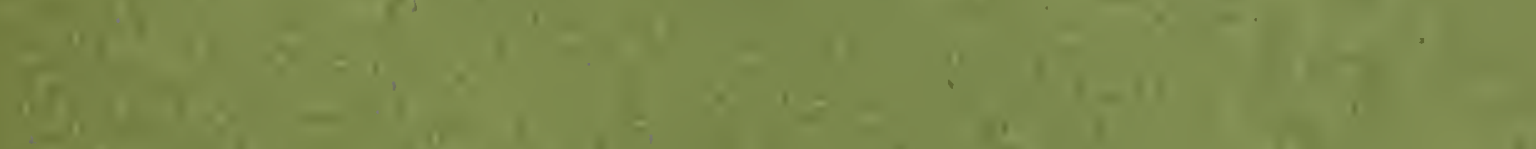

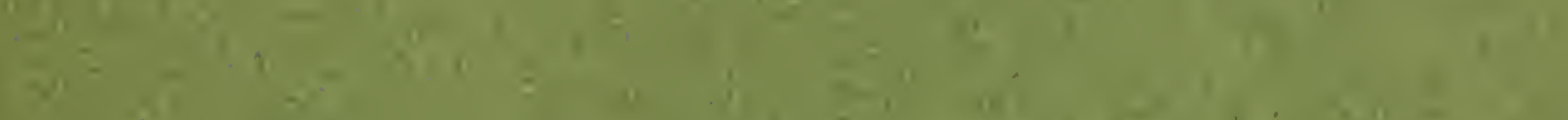

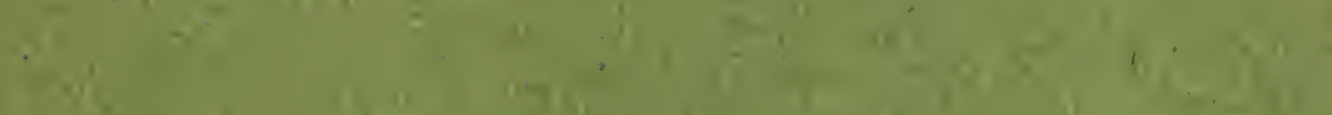

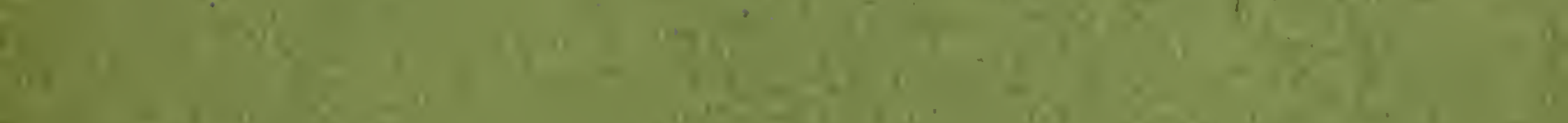

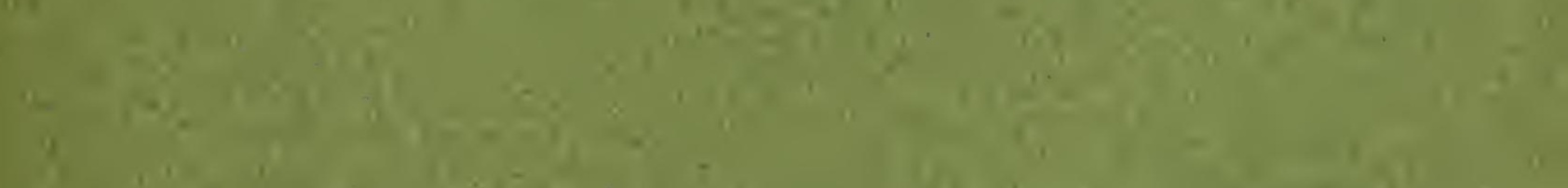

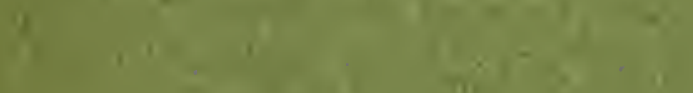

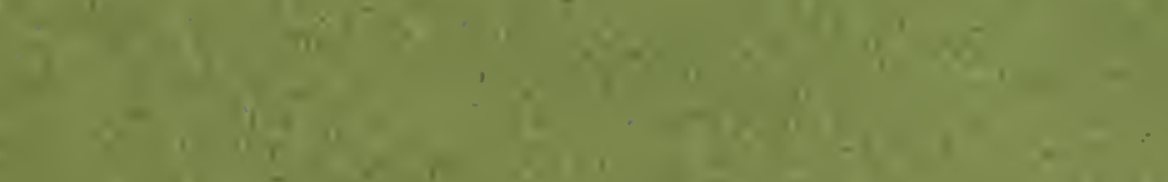

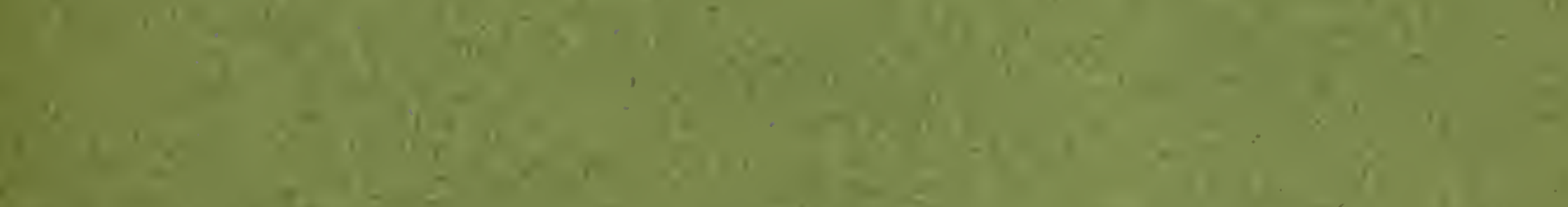
Kas

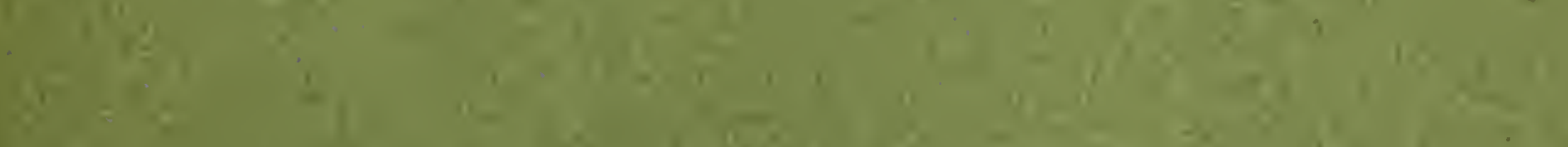

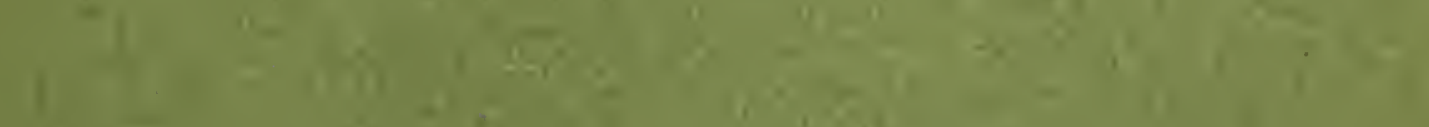

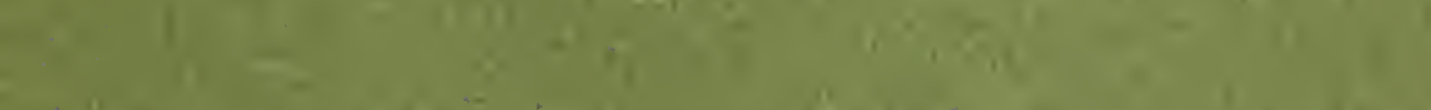

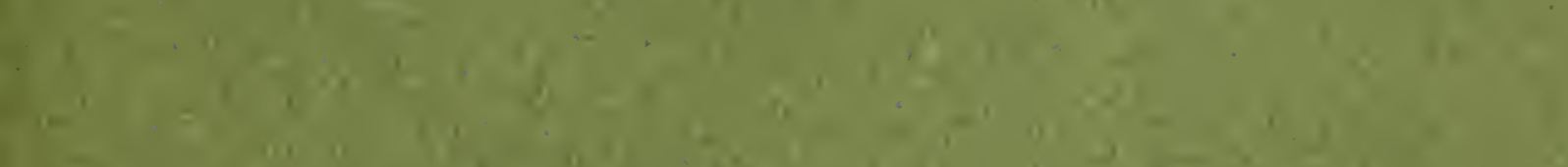

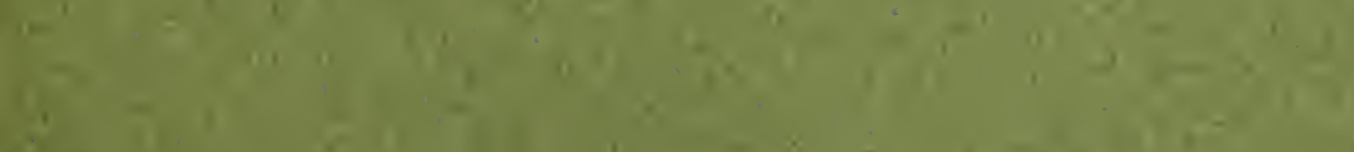

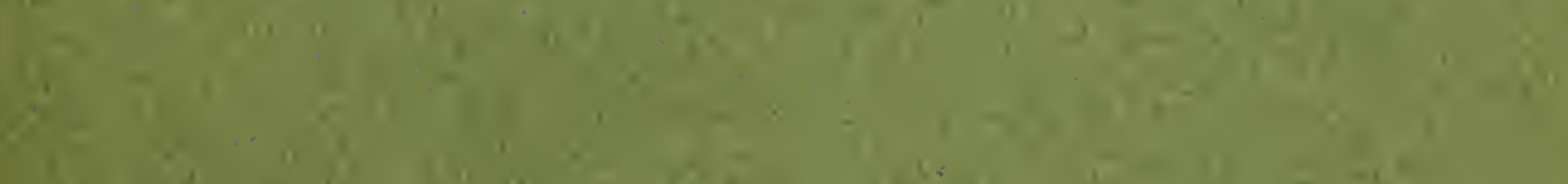

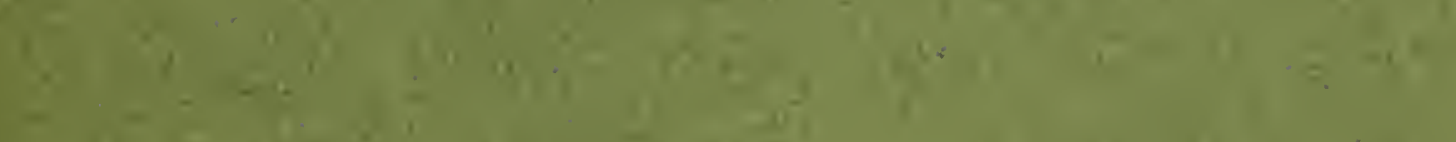

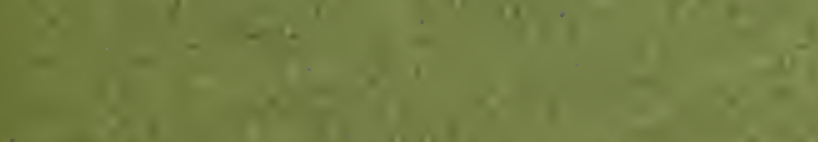
4

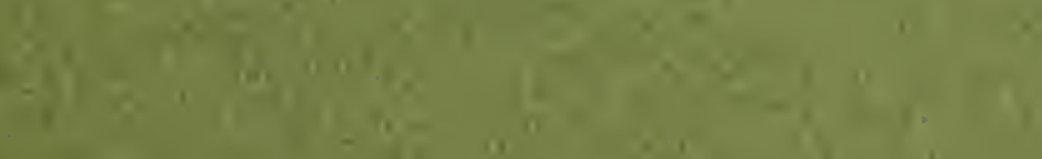



Syracuse, N. Y.

PAT. JAN. 21, 1908 
